\title{
Hydraulic Conductance in Tepal Growth and Extension of Vase Life with Trehalose in Cut Tulip Flowers
}

\author{
Hiroshi Wada \\ The United Graduate School of Agricultural Sciences, Ehime University, Tarumi, Matsuyama 790- \\ 8566, Japan \\ Mari Iwaya-Inoue \\ Department of Plant Resources, Graduate School of Bioresource and Environmental Science, Kyushu \\ University, Hakozaki, Higashi-ku, Fukuoka 812-8581, Japan \\ Mitsuru Akita and Hiroshi Nonami ${ }^{1}$ \\ Faculty of Agriculture and the United Graduate School of Agricultural Sciences, Ehime University, \\ Tarumi, Matsuyama 790-8566, Japan
}

\begin{abstract}
AdDitional InDEX wORDs. cell expansion, growth-effective turgor, growth-induced water potential, sucrose feeding, Tulipa gesneriana, turgor maintenance

Abstract. Two cultivars of tulip (Tulipa gesneriana L.) were used to check the effect of trehalose-feeding on longevity of vase life. 'Oxford' plants were grown from bulbs, and trehalose-fed cut flowers were compared with the intact plants grown in pots. 'Pink Diamond' flowers were obtained commercially as cut flowers from the market, and trehalose-feeding was examined by using only flower parts. In both cultivars of plants, it was confirmed that trehalosefeeding enhanced longevity of the vase life significantly at room temperature. Additionally, mechanisms of prolonging the vase life with trehalose-fed flowers were studied by comparing the water status in the zone of elongation of tulip tepals when their growth rates were modified with different treatments. In the elongating region of tulip tepals, cell elongation rates were linearly correlated to sizes of the growth-induced water potential regardless of treatments. It was found that trehalose-feeding reduced the hydraulic conductance, resulting in a decrease in cell elongation rates. Also, trehalose helped to maintain turgor of tepal cells for longer periods. Furthermore, trehalose enhanced pigmentation in tepals, and thus, trehalose is believed to have had a role in altering the metabolism in elongating cells and in reducing hydraulic conductivity in membranes.
\end{abstract}

Since petal growth occurs continuously until cell expansion is completed, petal growth is dependent mainly on cell expansion rates of petal tissues and determines the longevity of cut flowers (van Doorn, 1997). Recently, it was reported that trehalose, a nonreducing disaccharide consisting of two $\alpha$-glycosidically linked glucose units, enhanced the vase life of cut tulip flowers (Iwaya-Inoue and Nonami, 2003; Iwaya-Inoue and Takata, 2001). Trehalose is also known to enhance tolerance against desiccation and high temperature, probably by protecting membranes and enzymes from various stresses (Crowe et al., 1984; Hottiger et al., 1994; Lee et al., 1989). However, trehalose might be toxic for some tissues, because cell wall synthesis has been shown to be inhibited by trehalose feeding in dodder (Cascuta reflexa Roxb.) cells (Veluthambi et al., 1982), and growth of the shoot tip of dodder was completely suppressed in vitro (Veluthambi et al., 1981). Ikeda et al. (2000) reported that trehalose reduced hydraulic conductance in soybean [Glycine $\max (\mathrm{L}$.$) Merr.]$ embryos, resulting in growth retardation of embryos. If petal expansion rates are reduced by trehalose feeding, more time will be required for tepal growth to be completed, and thus longevity of the tulip may be prolonged.

Received for publication 26 Apr. 2004. Accepted for publication 10 Aug. 2004. Trehalose used in the present study was kindly supplied from Hayashibara Biochemical Labs, Shimoishii, Okayama, 700-0907, Japan. We thank Toshio Fukuyama for help in growing tulip plants, Naoko Sugimoto for assistance in the water status measurements, Masahiro Kato and Fumika Kakihara for help with the color difference meter used in this work.

'To whom reprint requests should be addressed. E-mail address: nonami@agr. ehime-u.ac.jp
Since water typically constitutes $90 \%$ to $95 \%$ of the mass of tulip tepals, an increase in cell volume can be considered to be nearly equivalent to the amount of water uptake in growing cells if transpiration is negligibly small. Because water must flow into the cells during cell growth, a water potential gradient exists between the water source and the cells as shown by Boyer (1974, 1985), Moltz and Boyer (1978), Nonami and Boyer (1987, 1993), Nonami et al. (1997), Ray and Ruesink (1963), and Silk and Wagner (1980). The size of the growth-induced water potential can be determined by the difference of water potential between elongating cells and the water source (Ikeda et al., 1999). The relationship between the relative growth rate in dimension growth $\left[G\right.$; expressed in units of per second $\left.\left(\mathrm{s}^{-1}\right)\right]$ and the growth-induced water potential $\left(\Psi_{\mathrm{o}}-\Psi_{\mathrm{w}}\right.$; MPa) can be expressed as:

$$
G=L\left(\Psi_{\mathrm{o}}-\Psi_{\mathrm{w}}\right)
$$

where $L$ [expressed in units of per second per megapascal $\left.\left(\mathrm{s}^{-1} \cdot \mathrm{MPa}^{-1}\right)\right]$ is hydraulic conductance associated with the growth process, and $\Psi_{\mathrm{o}}$ and $\Psi_{\mathrm{w}}$ are water potentials of the water source and the expanding cells, respectively.

During cell elongation, the cell wall must be extended outward by cell turgor $\left(\Psi_{\mathrm{p}} ; \mathrm{MPa}\right)$, and the relationship between relative growth rate and wall extensibility $\left(m ; \mathrm{s}^{-1} \cdot \mathrm{MPa}^{-1}\right)$ is given by the following equation (Green et al., 1971; Ray et al., 1972):

$$
G=m\left(\Psi_{\mathrm{p}}-Y\right)
$$

where $Y$ is the yield threshold turgor below which the force on the wall is too small to enlarge the wall irreversibly. Thus, $\left(\Psi_{\mathrm{p}}-Y\right)$ is the growth-effective turgor. When $G$ is plotted as a function of 
$\Psi_{\mathrm{p}}$, the slope of the line is $m$ and $Y$ is the intercept of the $\Psi_{\mathrm{p}}$ axis when $G=0$, provided that $m$ and $Y$ do not change.

Because plant cells elongate due to simultaneous water uptake and wall extension, Eqs. [1] and [2] can be combined (Lockhart, $1965 \mathrm{a}, 1965 \mathrm{~b})$ by applying the relation of $\Psi_{\mathrm{w}}=\Psi_{\mathrm{s}}+\Psi_{\mathrm{p}}\left(\Psi_{\mathrm{s}}\right.$ : osmotic potential), assuming that water potential in the protoplast is locally equilibrated with that in the apoplast in the zone of elongation (Hsiao et al., 1976; Moltz and Boyer, 1978; Nonami and Boyer, 1987, 1990a). Hence,

$$
G=\frac{m L}{m+L}\left(\Psi_{\mathrm{o}}-\Psi_{\mathrm{s}}-Y\right)
$$

Eq. [3], known as Lockhart's combined equation, was developed from a theory of cell enlargement (Lockhart, 1965a, 1965b), and is re-interpreted for tissue growth in the zone of elongation (Ikeda et al., 1999; Nonami and Boyer, 1990a). Simultaneous determinations of all parameters in Eq. [3] are not experimentally easy. Rearranging Eq. [3]:

$$
\frac{G}{L}+\frac{G}{m}=\left(\Psi_{\mathrm{o}}-\Psi_{\mathrm{w}}\right)+\left(\Psi_{\mathrm{p}}-Y\right)
$$

Eq. [4] is shown as the algebraic summation of Eqs. [1] and [2]. Because $L$ and $m$ are denominators in Eq. [4], $L \neq 0$ and $m$ $\neq 0$. In order to study which component contributes more predominantly to the growth in tulip tepals, parameters of $\left(\Psi_{\mathrm{o}}-\Psi_{\mathrm{w}}\right)$ and $\left(\Psi_{\mathrm{p}}-Y\right)$ were linearly separated and measured when $G$ was altered under various conditions. Because $\Psi_{\mathrm{w}}$ and $\Psi_{\mathrm{p}}$ in the zone of elongation and $\Psi_{\mathrm{o}}$ can be measured in the same tissue by using psychrometers, $G$ could be plotted against $\left(\Psi_{\mathrm{o}}-\Psi_{\mathrm{w}}\right)$ and $\Psi_{\mathrm{p}}$, and thus, slopes of the regression lines yield $L$ and $m$, respectively. The effect of excision on the wall relaxation in the zone of elongation while water potential was measured with the psychrometer could be evaluated by using the cell pressure probe. By assuming that $Y$ was not altered significantly when $G$ was changed, $Y$ was determined at $G=0$ from the plot of $G$ against $\Psi_{\mathrm{p}}$. Although the valid domain of Eq. [4] may not be completely overlapping with Eq. [1] and [2], we assume that both the water potential gradient and cell turgor are contributing to growth simultaneously under all conditions. This also means $L>0$ and $m>0$.

In the present study, after rates of flower development were adjusted in cut flowers by either modifying vase solution components or changing the temperature, the vase life of cut flowers and their growth rates were measured. Then, the hydraulic properties in the zone of elongation of tulip tepals were determined to understand why trehalose could enhance the vase life in cut flowers. Additionally, we discussed the effect of cell wall relaxation on psychrometric measurements after cross-checking turgor measurements with the cell pressure probe.

\section{Materials and Methods}

Plant materials. Tulip ('Oxford') bulbs, 12-13 cm in circumference were purchased from Niigata Prefecture Flower-Bulb Agricultural Cooperative Association, Niigata, Japan, in 1999-2002. Every year for the 4-year experiment period, bulbs were harvested in July and "dry"-stored at $20 \pm 1{ }^{\circ} \mathrm{C}$ and $70 \%$ to $90 \%$ relative humidity $(\mathrm{RH})$ until September. For forcing culture, bulbs were stored at $15{ }^{\circ} \mathrm{C}$ and $85 \%$ to $95 \%$ RH from 11 Sept. to 2 Oct., and further at $5 \pm 1{ }^{\circ} \mathrm{C}$ and $70 \%$ to $90 \% \mathrm{RH}$ for 9 weeks from 2 Oct. to $3 \mathrm{Dec}$. After these forcing treatments, bulbs were planted 10 per pot in $12.5-\mathrm{L}$ pots filled with a mixture of volcanic sands and vermiculite (1:3 by volume) on $4 \mathrm{Dec}$. Planting media in pots were equally watered with nutrient solution [(in $\mathrm{mM}) 3.02 \mathrm{NO}_{3}^{-}, 0.25$ $\mathrm{NH}_{4}^{+}, 0.25 \mathrm{PO}_{4}^{3-}, 1.51 \mathrm{~K}^{+}, 0.76 \mathrm{Ca}^{2+}, 0.38 \mathrm{Mg}^{2+}, 0.38 \mathrm{SO}_{4}^{2-}$, and (in $\mu \mathrm{M}$ ) $3.71 \mathrm{Fe}^{2+}, 1.17 \mathrm{Mn}^{2+} ; 8.73 \mathrm{BO}_{3}^{3-}, 0.14 \mathrm{Zn}^{2+}, 0.10 \mathrm{MoO}_{4}{ }^{2-}$, $0.06 \mathrm{Cu}^{2+}$ ) with electrical conductivity (EC) of $0.50 \mathrm{dS} \cdot \mathrm{m}^{-1}$ at $\mathrm{pH}$ 6.80. To measure water loss, containers were weighted every 3 d. After weighting, nutrient solution was added to maintain high water potential $(-0.02$ to $-0.04 \mathrm{MPa})$. The plants were grown in a growth chamber in complete darkness at $20 \pm 1{ }^{\circ} \mathrm{C}, 70 \%$ to $90 \%$ $\mathrm{RH}$ for 2 weeks until $17 \mathrm{Dec}$, then at $20 \pm 1{ }^{\circ} \mathrm{C}, 70 \%$ to $90 \%$ $\mathrm{RH}$ under $170 \mu \mathrm{mol} \cdot \mathrm{m}^{-2 \cdot} \cdot \mathrm{s}^{-1}$ of photosynthetic photon flux $(P P F)$ at $65 \mathrm{~cm}$ above the soil surface of the pot and the photoperiod of $14 \mathrm{~h}$ day/10 h night. To attain such $P P F$, every five pots were illuminated with two 37-W cool-white fluorescent lamps, which were fixed at $80 \mathrm{~cm}$ above the soil surface of the pot.

'Oxford' bulbs were also cultivated in an unheated greenhouse in Ehime Univ. in 1999-2000 and 2000-2001. Bulbs (740 in total) were planted in the beds with soil at $20-\mathrm{cm}$ intervals per plant with a depth of $15 \mathrm{~cm}$ from the soil surface on 13 Oct. Nutrients were supplied with $6250 \mathrm{~kg} \cdot \mathrm{ha}^{-1}$ of $2 \mathrm{~N}-1.7 \mathrm{P}-0.8 \mathrm{~K}$ composted poultry manure, $2031 \mathrm{~kg} \cdot \mathrm{ha}^{-1}$ of $0.7 \mathrm{~N}-0.3 \mathrm{P}-0.7 \mathrm{~K}$ composted dairy farm manure, and $2500 \mathrm{~kg} \cdot \mathrm{ha}^{-1}$ of dolomitic limestone as basal fertilizer, followed by $1176 \mathrm{~kg} \cdot \mathrm{ha}^{-1}$ of $8 \mathrm{~N}-3.5 \mathrm{P}-6.6 \mathrm{~K}$ compound fertilizer as supplemental fertilizer on 12 Mar. (during the first leaf expansion). Water was added to the soil to maintain high water potential if the soil surface appeared slightly dry. The lower half of the greenhouse walls were covered with plastic films, the upper half of the greenhouse sides were open to the ambient air, and the top of the greenhouse was covered by a reflective plastic film from 13 Oct. to 21 Feb. to protect against frosting/freezing and heat gain from radiation. As a result, the soil surface temperature in beds was maintained closely to the ambient air temperature. Flowering plants were harvested during the first $10 \mathrm{~d}$ of April.

Additional cut tulip (cv. Pink Diamond) flowers were obtained from a commercial grower just before their flower buds were opening and transported to the laboratory within $24 \mathrm{~h}$ after harvest. Uppermost internodes of unopened flower stems were trimmed to $15 \mathrm{~cm}$ and placed in test tubes containing $15 \mathrm{~mL}$ of one of the following test solutions: $50 \mu \mathrm{M}$ chloramphenicol (CAP) (control), $50 \mathrm{~mm}$ sucrose with $50 \mu \mathrm{M}$ CAP (sucrose treatment) and $50 \mathrm{~mm}$ trehalose with $50 \mu \mathrm{M}$ CAP (trehalose treatment), at $20 \pm 1{ }^{\circ} \mathrm{C}, 70 \%$ to $90 \% \mathrm{RH}$ with a $37-\mathrm{W}$ cool-white fluorescent lamp providing $20 \mu \mathrm{mol} \cdot \mathrm{m}^{-2} \cdot \mathrm{s}^{-1} \mathrm{PPF}$ with 14 -h day/10-h night photoperiods. Water potentials of each solution in control, sucrose treatment and trehalose treatment were $0,-0.12$, and -0.12 $\mathrm{MPa}$, respectively. Additionally, another set of cut flowers were placed in test tubes containing $15 \mathrm{~mL}$ of $50 \mu \mathrm{M}$ CAP solution and kept at $5 \pm 1{ }^{\circ} \mathrm{C}, 80 \pm 10 \% \mathrm{RH}$ under $14 \mathrm{~h}$ of illumination at 20 $\mu \mathrm{mol} \cdot \mathrm{m}^{-2} \cdot \mathrm{s}^{-1} P P F$. Forcing cultured-'Oxford' cut flowers were excised just at the edge of the top of bulbs and treated similarly as described above except for placing in test tubes containing $25 \mathrm{~mL}$ of each vase solution. Test solution was exchanged daily, and a few mm of flower stems were gently cut with a razor blade daily in the identical test solution so that xylem plugging was prevented during the flowering experiments.

Determination of VASE LIFE. To assess the vase life of cut flowers daily, we used the partially modified degree of opening defined by Iwaya-Inoue and Takata (2001). The state of opening of tepals was defined as follows: 0, unopened; 0.2, half-opened; 0.4 , fully opened; 0.6 , slightly changed color at the tepal edge; 0.8 , slightly changed color in the whole tepal and partially wilted; 
1.0, severely wilted in the whole tepal, as shown in Fig. 1. When the score reached 0.6 , the vase life of cut flowers was considered to be over (Jones and Hill, 1993; Jones et al., 1994). When tepals fell off naturally, the score was 1.0 , and then, the total life was considered to be over. The flower scores were averaged for five to 10 cut flowers in each treatment.

Color measurements. Color measurements were made at the center of 'Pink Diamond' tepal (2-mm-diameter measuring area) with a color difference meter (TC-6FD; Tokyo Denshoku Co., Tokyo), recording tepal chromaticity in terms of $\mathrm{L}^{*}, \mathrm{a}^{*}$, and $\mathrm{b}^{*}$ color space coordinates defined by the International Commission on Illumination (Hunter, 1975; McGuire, 1992). Chroma (vividness of color) was calculated with $\left(\mathrm{a}^{* 2}+\mathrm{b}^{* 2}\right)^{0.5}$ (Hunter, 1975).

Алатомy. Stomatal numbers per unit area in 'Pink Diamond' flowers were measured under a light microscope(IMT-2; Olympus Optical Co., Tokyo).

Measurements OF WATER BalanCE IN CUT Flowers IN THE DARK. To measure water loss during transpiration and water uptake during growth of cut flowers in the dark, the total mass of the cut flower with the vase solution and a test tube was weighted daily with an electric balance. An open space between the top of the test tube and a flower stem was covered entirely with paraffin film to prevent evaporation from the vase solution. The loss of water for transpiration was determined as weight differences between the measurement periods. Afterwards, the amount of water uptake during growth was determined by weighing changes in fresh weight of the cut flower between before and immediately after exchanging vase solution at each daily measurement.

Growth MEASUREMENTS. To measure local growth rates, tepal tissue was marked with India ink at 5-mm-intervals, and the intervals were measured with the caliper initially and after $24 \mathrm{~h}$.

Growth of 'Pink Diamond' and 'Oxford' tepals was measured directly with an extensiometer (Nonami and Boyer, 1990b) that consisted of a rotary differential transducer (RDT) (R30; Schaevitz Engineering, Pennsauken, N.J.) and a z-axis micro-stage (LV-241; Chuo Precision Industrial Co., Tokyo) having a micrometer with $2-\mu \mathrm{m}$ graduations over the displacement range of 2-mm length. The $\mathrm{z}$-axis micro-stage was fixed on a microscope stand that allowed the movement of the micro-stage over $220-\mathrm{mm}$ ranges in the z-direction with the accuracy of $10 \mu \mathrm{m}$. Hence, the position of the RDT could be adjusted freely in the z-direction, and calibration could be carried out with the micrometer of the micro-stage at any time without disturbing the plant materials. Flower stalks were placed in a $50-\mathrm{mL}$ beaker containing $50 \mathrm{~mL}$ of $50 \mu \mathrm{M} \mathrm{CAP}$. The tip of the tepal was clamped with a small clip, connected to a nylon thread looped over two pulleys and then joined to the RDT, so that the extension of the tepal due to growth could rotate a bar fixed on the RDT. The reference bar was connected at the position of the uppermost node just below the flower. Weights of the clip (1.00 g) and the thread were counterbalanced by applying $8.18 \mathrm{~g}$ of weight at the other side of the RDT bar. Extension could occur downward by overcoming contact resistance of the pulley rotation as the force $(0.070 \mathrm{~N})$ was applied to RDT. Tepals could grow without restriction in the test solution while attached to the RDT. Solutions of $50 \mu \mathrm{M}$ CAP were changed to those of either $50 \mathrm{~mm}$ sucrose plus $50 \mu \mathrm{M}$ CAP or $50 \mathrm{~mm}$ trehalose plus $50 \mu \mathrm{M}$ CAP. Changes in output of the RDT were recorded with a pen recorder. To minimize the effects of light on growth, experiments were conducted (at $25 \pm 1{ }^{\circ} \mathrm{C}, 80 \pm 10 \% \mathrm{RH}$ for ' Oxford' tepals, and at $20 \pm 1{ }^{\circ} \mathrm{C}, 80 \pm 10 \% \mathrm{RH}$ for 'Pink Diamond' tepals) under a green safelight (green fluorescent bulb wrapped in green plastic sheet having maximum transmission at $525 \mathrm{~nm}$ and negligible transmission below $475 \mathrm{~nm}$ and above $575 \mathrm{~nm}$ ). Growth rate of tepals were estimated from the slope per unit time of the length displacement recorded on the chart paper.

Water status measurements. Tepal tissues were sampled under the green safe light to minimize the effects of transpiration on the water status of plants. Each tissue was excised from the plant and rapidly transferred to a humidity box for further dissection. All subsequent tissue manipulations were performed under saturating humidity inside the box to minimize water loss from the tissue after excision. The water status of tepal tissue was determined with the isopiestic psychrometers at $25 \pm 0.0005$ ${ }^{\circ} \mathrm{C}$ (Boyer, 1995). Tepal sections $\left(\approx 1.0 \mathrm{~cm}^{2}\right)$ were placed at the bottom of a psychrometer cup that was coated with melted and resolidified petrolatum (Boyer, 1967). After water potential was measured, osmotic potential of the tissue was determined in the same tissue immediately after freezing at $-80{ }^{\circ} \mathrm{C}$ and thawing at $25^{\circ} \mathrm{C}$ (Ehlig, 1962; Nonami and Boyer, 1987). Turgor was calculated by subtracting osmotic potential from water potential. Balancing pressure of the xylem tension (i.e., the magnitude of the matric potential in the apoplast) of tepal tissues was measured with a pressure chamber (Boyer, 1967; Scholander et al., 1965). Tepals were cut horizontally at the position of $10 \mathrm{~mm}$ from the

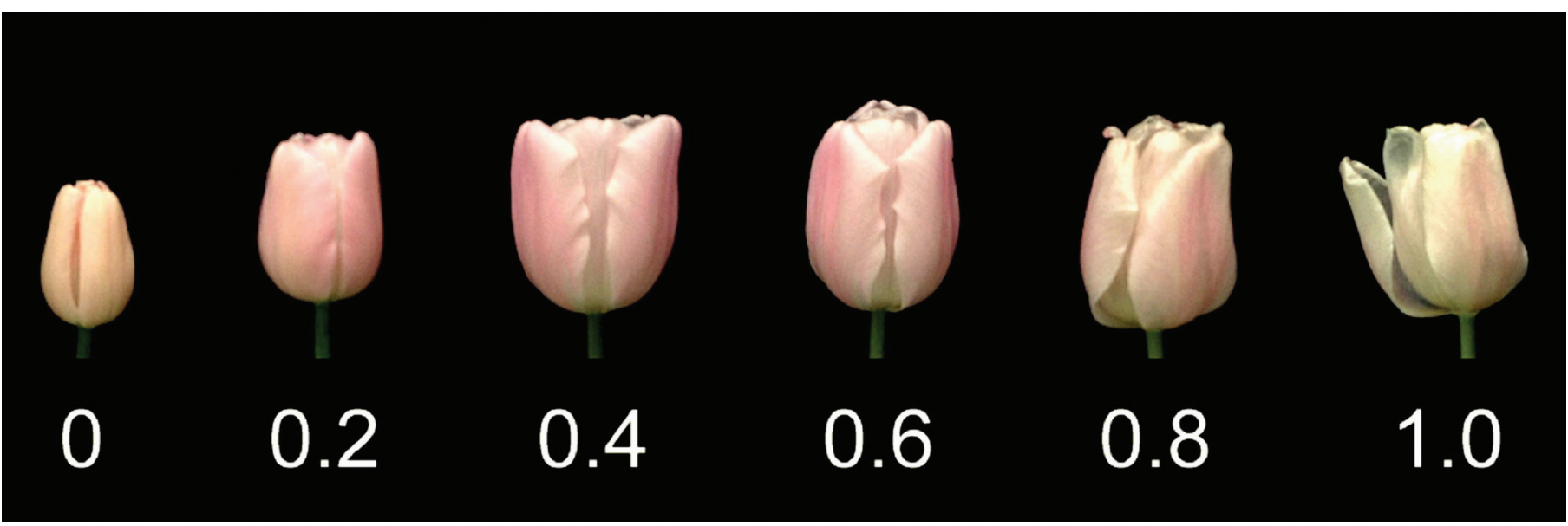

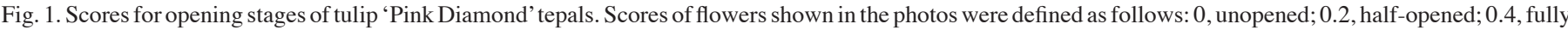
opened; 0.6 , slightly changed color at the tepal edge; 0.8 , slightly changed color in the whole tepal and partially wilted; 1.0 , severely wilted in the whole tepal. 
uppermost node and immediately transferred to the humidity box. Subsequently, an inverted " $T$ "-shaped cut was made at the cut end so that the protruding main vein could be inserted through the septum of a pressure chamber (Fig. 2A). The cut surface, except for the main vein at the end of the inverted "T"-shaped cut tissue, was covered with petrolatum. Pressure was applied with compressed air, bubbled through water in the chamber. After measuring the balancing pressure, the tissue was overpressured until the apoplast solution appeared, and 0.5 to $1.0 \mu \mathrm{L}$ of apoplast solution was collected with a microsyringe (Fig. 2A). The apoplast osmotic potential in tepals was measured with the psychrometer by putting the apoplast solution on the psychrometer sensor loop (Nonami and Boyer, 1987).Afterwards, a part of the mature region in the cut tepal was removed, and its water status was measured with the isopiestic psychrometer as described above.

ESTIMATION OF WALL RELAXATION BY EXCISION. In order to check the effect of wall relaxation caused by excision in the elongating tissue on the water potential measurement in tissues isolated from the zone of elongation, cell turgor in intact tepal tissue was measured with a cell pressure probe (Hüsken et al., 1978). After cell turgor measurements, the tissue was excised, and water potential of the tissue was measured with the isopiestic psychrometer. Subsequently, the tissue was taken out from the psychrometer chamber, and then, cell turgor of the tissue was measured with the pressure probe. The differences in cell turgor between before and after excision were considered to be pressure relaxation caused by wall relaxation induced by excision in the elongating tissue.

For such an experiment, cell turgor of the epidermal cells in the zone of elongation (1.0 to $2.0 \mathrm{~cm}$ from the uppermost node) in intact 'Pink Diamond' outer tepals at score 0.1 (see Fig. 1) was measured by using the pressure probe under a green safelight. Prior to the measurement, the abaxial side of tepals and the uppermost internode were coated with petrolatum. And further, tepals were covered with wet tissue paper to minimize water loss during the pressure probe measurements (Nonami and Boyer, 1993). The measured tissue segments $\left(\approx 1.0 \mathrm{~cm}^{2}\right)$ were removed and placed in 1.5-mL microcentrifuge tubes. Cell sap solutions were collected after the sample was frozen immediately at $-80^{\circ} \mathrm{C}$ and thawed and then spun for $5 \mathrm{~min}$ at $18,500 \mathrm{~g}_{\mathrm{n}}$ in a high speed micro refrigerated centrifuge(MTX-150; Tomy Seiko Co., Tokyo). Meanwhile, after pressure probe measurement, the tissue segments $\left(\approx 1.0 \mathrm{~cm}^{2}\right)$ which were located at the symmetrical position with respect to the mid vein in the tissues measured with the pressure probe, were removed and placed at the bottom of a psychrometer cup in the humidity box so that the petrolatum-coated abaxial side was placed with the bottom-side down, and water potential of these tissues was determined with the psychrometry. After the water potential measurements, samples were removed from the cup in the humidity box and then the turgor of epidermal cell in the samples was measured with the pressure probe again. Further, osmotic potential of the same tissue samples was determined after freezing at $-80{ }^{\circ} \mathrm{C}$ and thawing. Osmotic potential of cell sap solution, tissue water potential and tissue osmotic potential were measured with the psychrometer. In psychrometric measurements, turgor in the zone of elongation was calculated by obtaining the difference between water potential and osmotic potential.

\section{Results}

Measurements of the Water status in the mature tePals. In the zone of maturation in individual tepal tissues, the matric
A

Pressure chamber
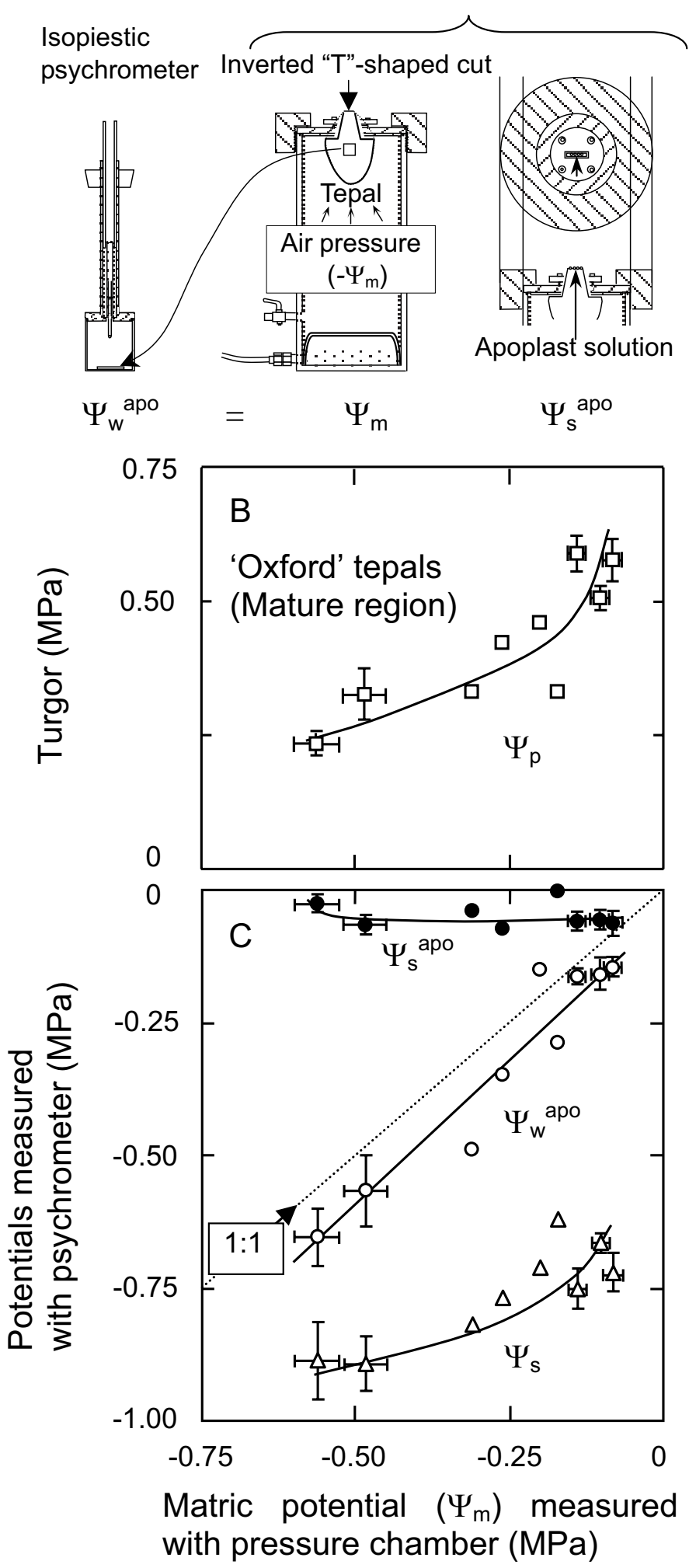

Fig. 2. Schematic diagrams of the water status measurement with the pressure chamber and the isopiestic psychrometer $(\mathbf{A})$, and turgor $\left(\Psi_{\mathrm{p}}\right)(\mathbf{B})$, and the apoplast osmotic potential $\left(\Psi_{\mathrm{s}}\right.$ apo $;$ ) , water potential $\left(\Psi_{\mathrm{w}} ; \bigcirc\right)$, and osmotic potential $\left(\Psi_{s} ; \Delta\right)(\mathbf{C})$ in the mature region of 'Oxford' tepals measured with the isopiestic psychrometer plotted against the matric potential measured with a pressure chamber. Using harvested elongating tepals, the inverted " $\mathrm{T}$ "-shaped cut was made to insert to a pressure chamber (see "Materials and Methods") as shown in A. Vertical and horizontal bars indicate SE $(n=3-5)$. A slanting dotted line with (1:1) in B indicates an equipotential line. The regression line is $y=1.11 x-0.05$ with $r^{2}=0.90$. 
potential (i.e., the negative of the balancing pressure), osmotic potential of the apoplast solution $\left(\Psi_{\mathrm{s}} \mathrm{apo}\right)$, tissue water potential $\left(\Psi_{\mathrm{w}}\right)$, tissue osmotic potential $\left(\Psi_{\mathrm{s}}\right)$, and turgor $\left(\Psi_{\mathrm{p}}\right)$ were determined simultaneously with the pressure chamber and the isopiestic psychrometer (Fig. 2A). Fresh weight and dry weight of outer tepals in field-cultured 'Oxford' plants used for this experiment were $($ mean $\pm S D) 4.47 \pm 0.45 \mathrm{~g}(\mathrm{n}=8)$ and $0.38 \pm 0.03 \mathrm{~g}(\mathrm{n}=8)$, respectively; thus, the water mass of the tepal was $4.09 \pm 0.42 \mathrm{~g}$ $(\mathrm{n}=8)$. Because the volume of extracted apoplast solution per tepal was $0.5-1.0 \mu \mathrm{L}$, the ratio of the apoplast sap mass to the total water mass per tepal was estimated to be $<0.024 \%$. Because the volume of extracted apoplast solution for the $\Psi_{\mathrm{s}}$ apo measurement was negligibly small, the $\Psi_{\mathrm{w}}$ measured in the tepal tissue with the psychrometer should not have been affected significantly even after the tissue was used for the extraction of the apoplast solution with the pressure chamber.

Under transpiring conditions, water potentials of the mature zone of tepals decreased to lower than $-0.6 \mathrm{MPa}$, although plants were grown in well-watered soil. When the matric potential became more negative, turgor tended to decrease (Fig. 2B), and this decrease was related to transpiration. Even at $-0.6 \mathrm{MPa}$ of the matric potential, the $\Psi_{\mathrm{s}}$ apo was $-0.05 \mathrm{MPa}$, indicating that solute concentration in the apoplast was low (Fig. 2C). In the mature zone of tepal tissue, the $\Psi_{\mathrm{s}}$ apo was always kept high in all ranges of matric potentials of the tissue (Fig. 2C), and thus, solute accumulation in the apoplast was not observed under the present cultivation condition. The water potential measured with the psychrometer was almost 1:1 in relation with the matric potential measured with the pressure chamber with the shift of the size of $\Psi_{\mathrm{s}}^{\text {apo }}$. Thus, it was confirmed that water potential $=\Psi_{\mathrm{s}}$ apo + matric potential as found in soybean seedlings by Nonami and Boyer (1987). Also, this demonstrated that the measurements could be done accurately in the mature zone of tepals with both the psychrometer and the pressure chamber.

The VASE LIFE OF TEPALS. Growth of the control and sucrose-fed tulip flowers occurred rapidly from Score 0 to Score 0.4 in the first $2 \mathrm{~d}$ after treatments (Fig. 3A). In trehalose treatment, developments in scores from 0 to 0.4 took $\approx 5 \mathrm{~d}$ after the treatment (Fig. $3 \mathrm{~A})$. Thus, it is apparent that trehalose-feeding delayed development of tulip tepals, resulting in longer vase life with trehalose. Because this developmental delay was related to changes in the size of flowers, it is most likely that speed of cell elongation was affected by trehalose feeding. The sucrose-containing solution enhanced the vase life compared with the control solution, and the trehalose-containing solution further enhanced the vase life more than the sucrose-containing solution (Fig. 3A). Turgor of the mature tissue of tepals was maintained highest for longer periods in the trehalose-containing solution (Fig. 3B). Flowers kept in the trehalose-containing solution looked more pink than the control and the sucrose-treated flowers, since the chroma of the trehalose-treated flowers was the highest (Fig. 3C). Thus, trehalose-feeding extended the vase life of tulip flowers by maintaining turgor in tepal tissue, and additionally, tulip flowers treated with trehalose looked more brilliant by increasing deeper pigmentation in tepal tissues.

Stomatal Frequency IN TePals. The zone of elongation in 'Pink Diamond' tepals was located between 0 and $40 \mathrm{~mm}$ from the uppermost node of the stem (Fig. 4A). Stomata were the most abundant in the adaxial side of outer tepals in tulip flowers (Fig. $4 \mathrm{~B}$ and $\mathrm{C}$ ). The ratio of stomatal frequency between the zone of elongation and that of maturation was similar in both sides of the inner and outer tepals (Fig. 4), and thus, differentiation of stomatal
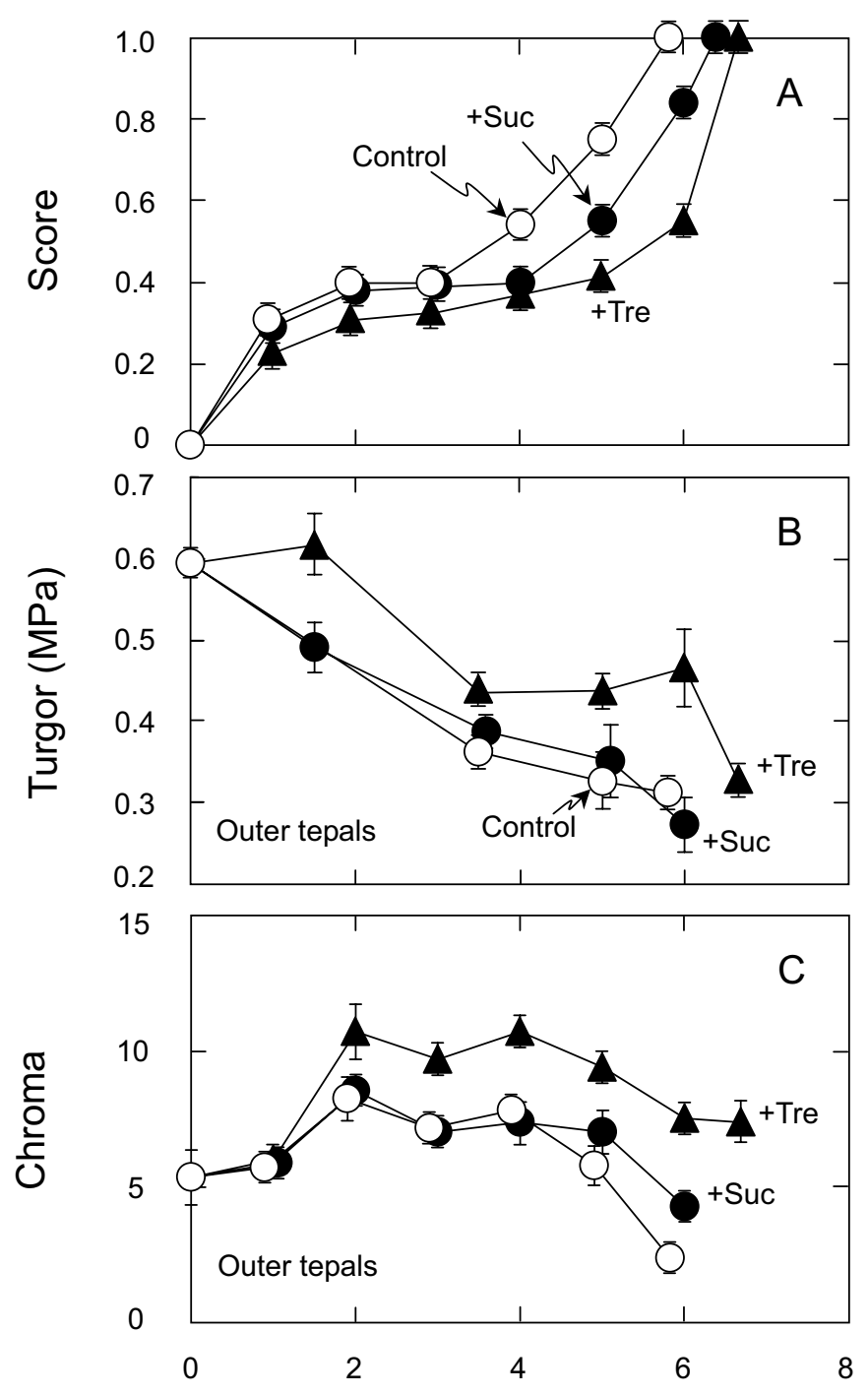

Time after treatment (d)

Fig. 3. Scores of flower opening defined in Fig. 1 (A), turgor (B), and chroma (C) of tepals of 'Pink Diamond' cut flowers kept in each vase solution, i.e., 50 um chloramphenicol (CAP) (Control), $50 \mathrm{~mm}$ sucrose plus $50 \mu \mathrm{M} \mathrm{CAP}(+\mathrm{Suc})$ and $50 \mathrm{~mm}$ trehalose plus $50 \mu \mathrm{M}$ CAP (+Tre) with respect to time after treatments. Vertical bars at data points indicate SE $(n=3-7)$. Chroma was measured on the mature region in the abaxial surface of outer tepals.

organs was considered completed at Score 0.1. Stomata generally begin to develop in a leaf shortly before the main period of meristematic activity in the epidermis is completed and continue to arise through a considerable part of the later extension of the leaf by cell elongation (Esau, 1977). Because meristematic activity in tepals of Score 0.1 was considered over, it is most likely that tepal growth in tulip flowers used in the present study was associated only with processes of cell elongation. Therefore, when local growth rates in tepals decreased as maturation proceeded, it was considered that the distance between stomata increased proportionally.

WATER LOSS AND WATER UPTAKE IN THE DARK. When the water balance of 'Oxford' cut flowers treated with sucrose- and trehalose-containing solution on $3 \mathrm{~d}$ after the treatment was measured in the dark for $24 \mathrm{~h}$, the fresh weight of the cut flower, the rate of water loss for transpiration and the water uptake rate for growth was $44.07 \pm 1.43 \mathrm{~g}, 5.70 \pm 0.86 \mathrm{~g} \cdot \mathrm{d}^{-1}$, and $8.16 \pm 1.20 \mathrm{~g} \cdot \mathrm{d}^{-1}$ for 

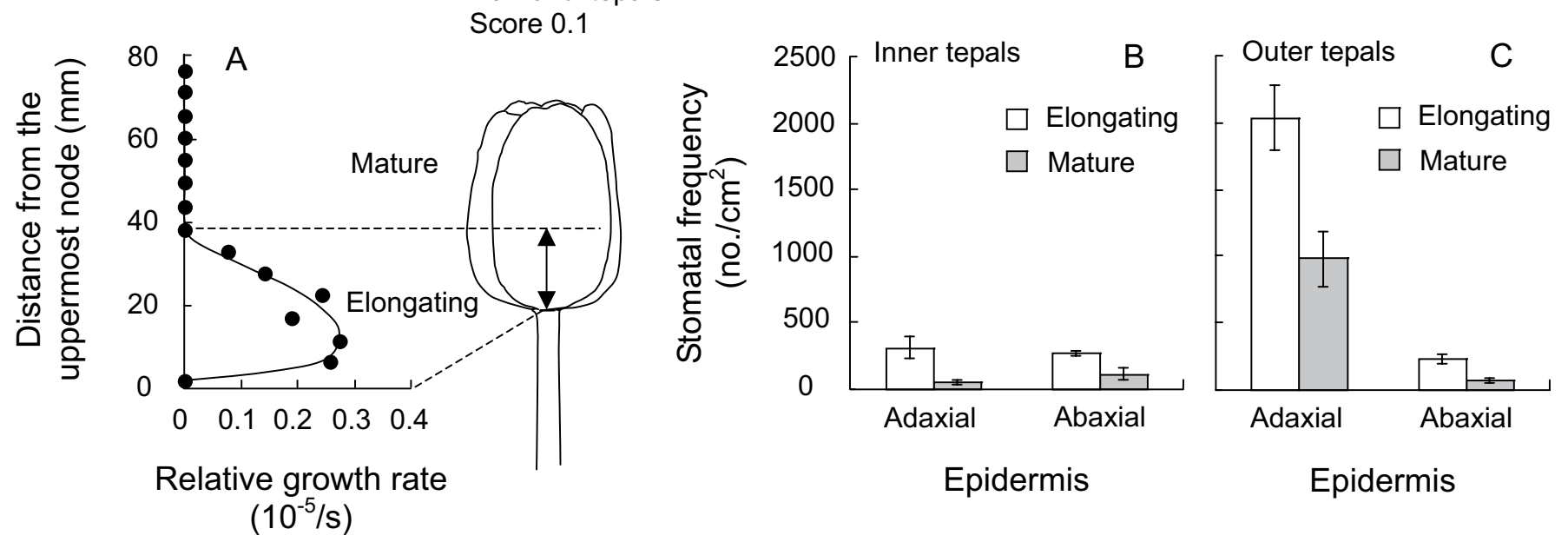

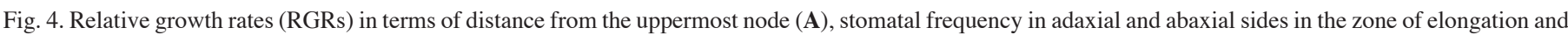

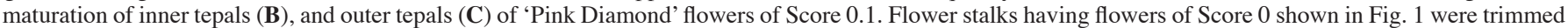

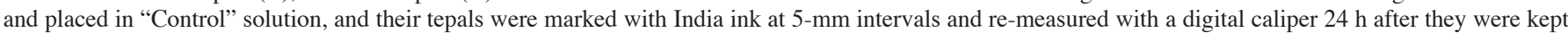
at $20 \pm 1{ }^{\circ} \mathrm{C}, 80 \% \pm 10 \% \mathrm{RH}$ in the dark. Vertical bars in B and C indicate 95\% confidence intervals calculated from the Student's $t$ distribution.

sucrose-containing solution, and $38.90 \pm 2.61 \mathrm{~g}, 3.45 \pm 0.87 \mathrm{~g} \cdot \mathrm{d}^{-1}$,

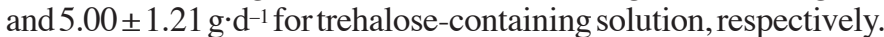
The amount of water loss for transpiration was much smaller than that of water uptake for growth in both solution, indicating that transpiration could be inhibited significantly in the dark. Additionally, tepals of flowers kept in the dark always were more tightly closed than those in the light. Because the outer tepals have much more stomata than the inner tepals (Fig. 4), when transpiration was much less in the dark, it was most likely that the outer tepals were kept more turgid in the dark than in the light, resulting in more closed tepals in the dark. Thus, it is apparent that stomata of tepals were mostly closed in the dark.

THE WATER STATUS OF DIFFERENT LOCATIONS IN TEPAL TISSUES. In 'Oxford' tepals, the zone of elongation was located between 0 and $55 \mathrm{~mm}$ from the uppermost node, and the most actively growing position was at $\approx 10 \mathrm{~mm}$ from the uppermost node (Fig. 5C). To eliminate the influence of transpiration, the water status was measured while flowers were kept in the dark. In the most actively growing location, water potential, osmotic potential and turgor were the lowest, and became gradually higher when measured positions were moved toward the mature zone of tepals (Fig. $5 \mathrm{~A}$ and B). The water potential of the mature zone of tepal tissue was similar to that of mature stem and mature root tissues [i.e., $($ mean $\pm S D)-0.19 \pm 0.04 \mathrm{MPa}(\mathrm{n}=18)$ for stems and -0.21 $\pm 0.10 \mathrm{MPa}(\mathrm{n}=16)$ for roots].

CUT FloWer GROWTH WITH SUCROSE OR TREHALOSE. Because 'Pink Diamond' is a smaller flower than 'Oxford' and air temperature at which 'Pink Diamond' flowers were kept was lower than that at which 'Oxford' flowers were kept, growth rates of 'Pink Diamond' were relatively lower than those of 'Oxford' (Fig. 6). When the control solution in the vase was replaced by the sucrose-containing solution, the growth rate became 1.95 times larger than the control in 'Oxford' and 1.35 times larger than the control in 'Pink Diamond' (Fig. 6). In both cases, there
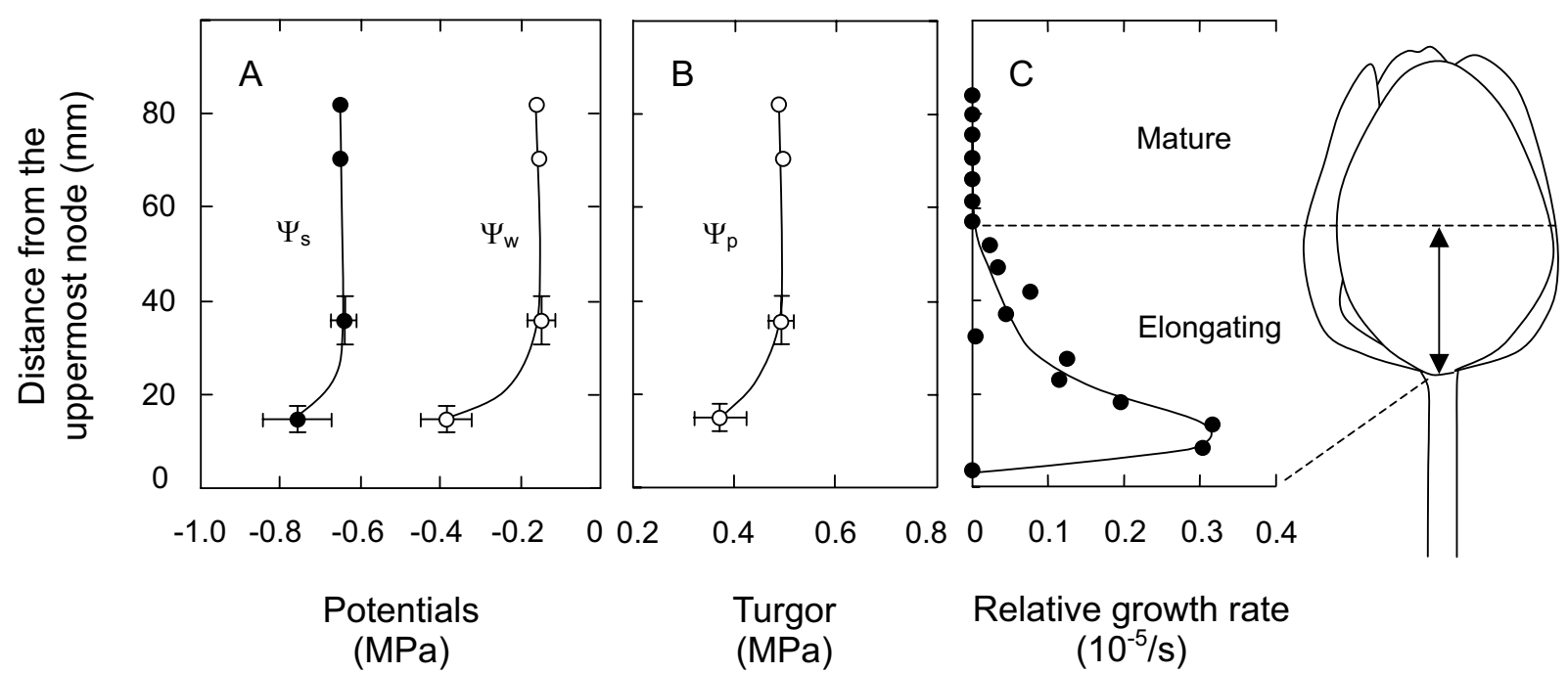

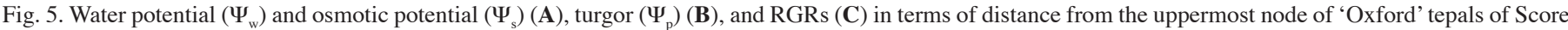
0.1 . Vertical and horizontal bars in A and B indicate SE $(n=3-4)$. 


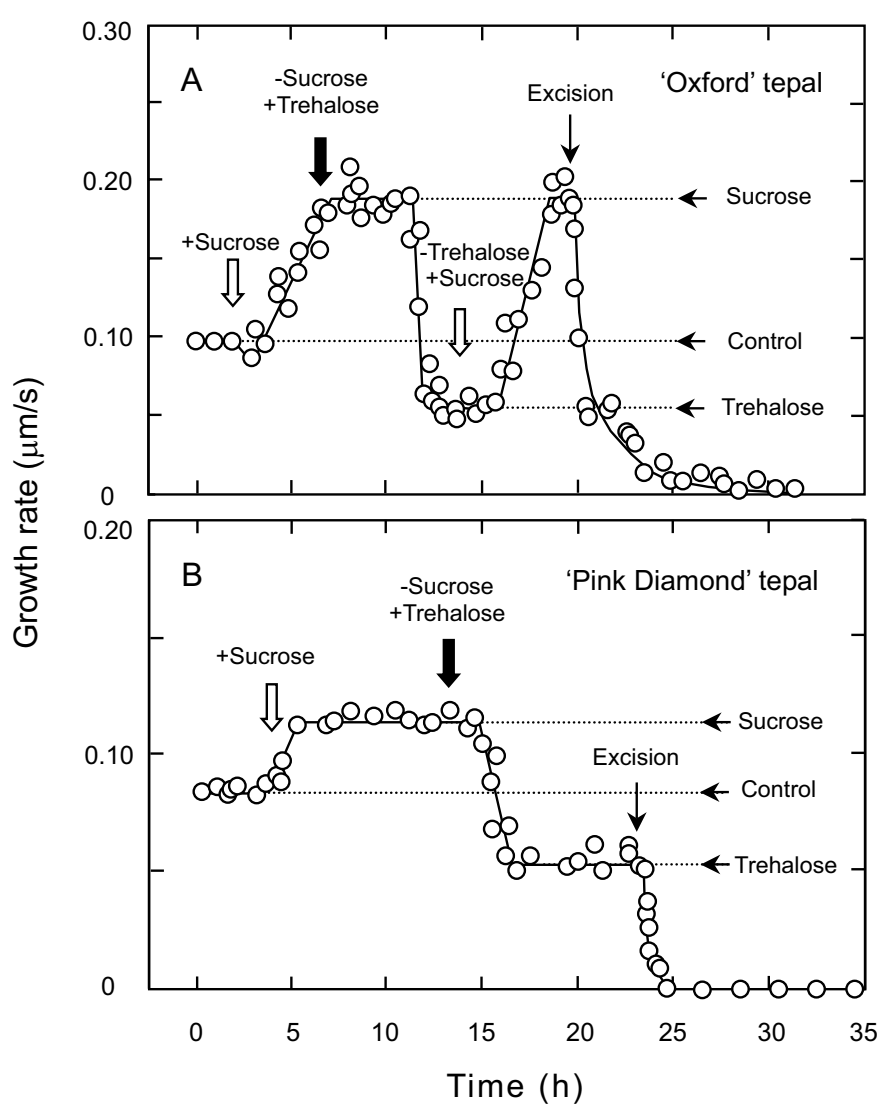

Fig. 6. Growth rates of an 'Oxford' tepal (A) and a 'Pink Diamond' (B). While the tepal was fixed to the rotary differential transducer, the vase solution was changed from Control (50 $\mu \mathrm{m}$ chloramphenicol) to + Suc $(50 \mathrm{~mm}$ sucrose plus $50 \mu \mathrm{m}$ chloramphenicol), and further to +Tre $(50 \mathrm{~mm}$ trehalose plus $50 \mu \mathrm{M}$ chloramphenicol) in A and B. In A, the vase solution was further changed to +Suc. Thereafter, the flower stalk was excised. The measurements were conducted under the green safelight at $25 \pm 1{ }^{\circ} \mathrm{C}$ and $80 \% \pm 10 \% \mathrm{RH}$ for 'Oxford' tepal (A) and at $20 \pm 1{ }^{\circ} \mathrm{C}$ and $80 \% \pm 10 \% \mathrm{RH}$ for 'Pink Diamond' tepal (B). Open downward arrows with "+ Sucrose", closed downward arrows with "-Sucrose + Trehalose", open downward arrows with "-Trehalose + Sucrose" and single line downward arrows with 'Excision' indicate changing the vase solution to + Suc, changing from + Suc to + Tre, changing from + Tre to + Suc and excising the flower stalk to cut the water pathway, respectively.

was a significant time lag between the growth response and the solution exchange time, and it was considered that it took a few hours for the sucrose solution to reach the growing regions in tepals under nontranspiring conditions. After reaching the steady growth rate, the sucrose-containing solution was replaced by the trehalose-containing solution. After adding the trehalose, the growth rate only reached $56 \%$ of that of the control in 'Oxford' and $60 \%$ of that of the control in 'Pink Diamond' (Fig. 6). After returning to the sucrose-containing solution, the growth rate recovered as before in 'Oxford' tepals (Fig. 6A). Stem excision cut the pathway of water absorption, resulting in the inhibition of tepal growth in both 'Oxford' and 'Pink Diamond' (Figs. 6 $A$ and $B$ ). It became apparent that adding sucrose increased cell elongation rates and adding trehalose decreased cell elongation rates in tepals of cut tulip flowers.

COMPARISONS AMONG TREATMENTS IN TEPAL GROWTH. In 'OXford' plants, tepal growth of cut flowers was compared with that of intact plants grown in pots. In order to eliminate the effect of photosynthesis on growth, all growth measurements in tepals of 'Oxford' plants were conducted in the dark. When 'Oxford' cut flowers were kept in the sucrose-containing solution, tepal growth was faster than that of intact plants (Fig. 7A). When 'Oxford' cut flowers were kept in the trehalose-containing solution, tepal growth was slower than that of intact plants (Fig. 7A). However, when 'Oxford' cut flowers were kept in CAP solution at $5{ }^{\circ} \mathrm{C}$, tepal growth was slower than in the trehalose-feeding treatment (Fig. 7A).

In 'Pink Diamond' experiments, only cut flowers without leaves were used and kept under lighting conditions during the experiments. The control vase solution was $50 \mu \mathrm{M}$ CAP, and its water potential was $\approx 0 \mathrm{MPa}$. Tepal growth in the sucrose-containing solution was better than that in the control although the sucrose-containing solution ( $-0.12 \mathrm{MPa}$ of water potential) had slightly lower water potential than the control solution (Fig. 7B), indicating that sucrose was contributing to cell elongation. Tepal growth in the trehalose-containing solution was significantly slower than that in the control solution (Fig. 7B). When 'Pink Diamond' flowers were kept at $5^{\circ} \mathrm{C}$, tepal growth was significantly

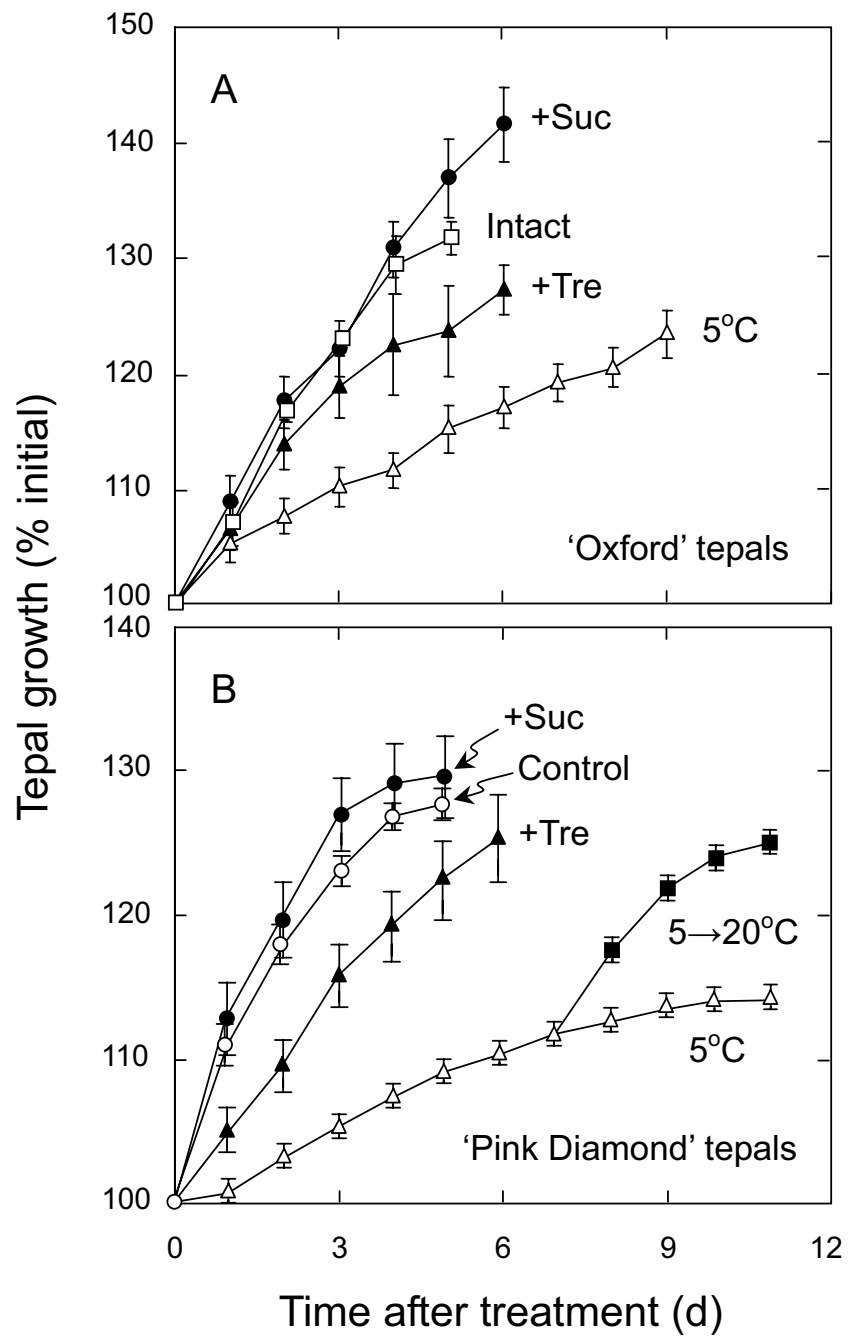

Fig. 7. Relative longitudinal length in tepal growth after the vase solution treatments in 'Oxford' (A) and 'Pink Diamond' (B) tepals. In A, "Intact ( $(\square)$ ", indicates intact 'Oxford' plants grown in pots. "+Suc $(\mathbf{O})$ ", "+Tre $(\mathbf{\Delta})$ " and " $5{ }^{\circ} \mathrm{C}(\Delta)$ " indicate cut flowers kept in the vase solution containing sucrose at $20{ }^{\circ} \mathrm{C}$, cut flowers kept in the vase solution containing trehalose at $20^{\circ} \mathrm{C}$ and cut flowers kept in the vase solution of $50 \mu \mathrm{M} \mathrm{CAP}$ at $5{ }^{\circ} \mathrm{C}$, respectively. In $\mathrm{B}, 15-\mathrm{cm}$-long cut flowers of 'Pink Diamond' were used in all treatments, and

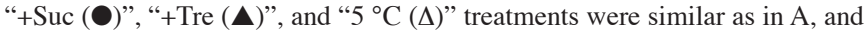
"Control $(\bigcirc)$ " and " $5 \rightarrow 20^{\circ} \mathrm{C}(\boldsymbol{\square})$ " indicate cut flowers kept in Control solution at $20{ }^{\circ} \mathrm{C}$ and cut flowers transferred from 5 to $20^{\circ} \mathrm{C}$, respectively. Vertical bars indicate SE $(\mathrm{n}=3-10)$. 

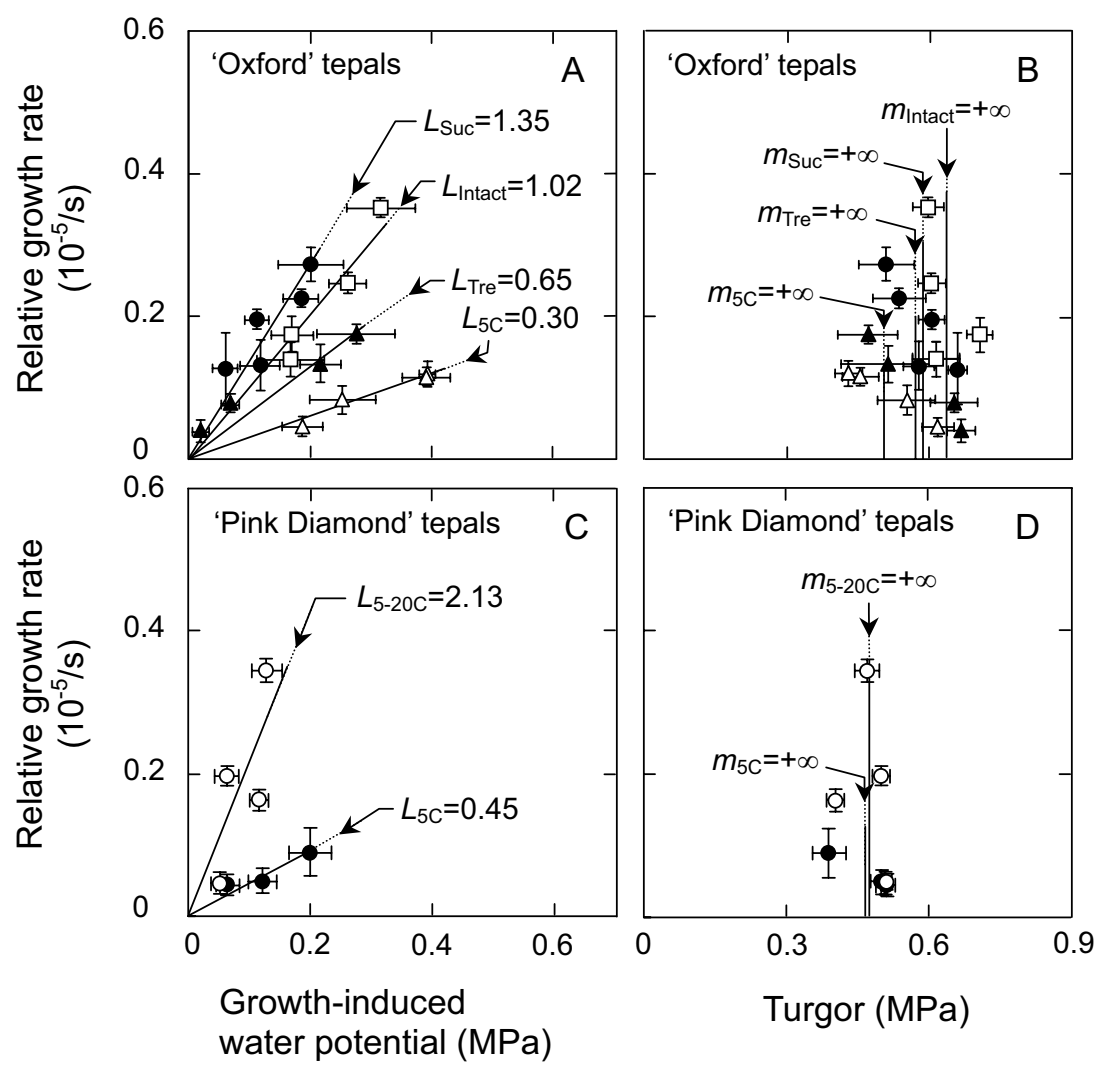

Fig. 8. RGRs plotted against sizes of the growth-induced water potential $(\mathbf{A}, \mathbf{C})$ and against turgor $(\mathbf{B}, \mathbf{D})$ in the zone of elongation of 'Oxford' $(\mathbf{A}, \mathbf{B})$ and 'Pink Diamond' $(\mathbf{C}, \mathbf{D})$ tepals. Symbols indicate the same as Fig. 7. Vertical and horizontal bars indicate SE $(n=3-11)$. The growth-induced water potential was calculated by subtracting the water potential of expanding tepals from that of water source. In A and $\mathrm{C}$, the hydraulic conductance $(L)$ was obtained from the slope of the line. The regression lines are as follows; (A) $y=1.02 x$ with $r^{2}=0.91$ for intact flowers $\left(L_{\text {Intact }}=\right.$ $1.02), y=1.35 x$ with $r^{2}=0.67$ for the sucrose treatment $\left(L_{\mathrm{Suc}}=1.35\right), y=0.65 x$ with $r^{2}=0.82$ for the trehalose treatment $\left(L_{\mathrm{Tre}}=0.65\right)$, and $y=0.30 x$ with $r^{2}=0.95$ for the $5^{\circ} \mathrm{C}$ treatment $\left(L_{5 \mathrm{C}}\right.$ $=0.30) ;(\mathbf{C}) y=2.13 x$ with $r^{2}=0.55$ for treatment transferring $5^{\circ} \mathrm{C}$ to $20{ }^{\circ} \mathrm{C}\left(L_{5-20 \mathrm{C}}=2.13\right)$ and $y$ $=0.45 x$ with $r^{2}=0.78$ for the $5{ }^{\circ} \mathrm{C}$ treatment $\left(L_{5 \mathrm{C}}=0.45\right)$. In B and D, wall extensibility $(m)$ was considered to be infinitely large, because wall extensibility must be positive.

reduced (Fig. 7B). When $5^{\circ} \mathrm{C}$-kept flowers were transferred to $20^{\circ} \mathrm{C}$, tepal growth increased and finally they grew almost as large as the control flowers (Fig. 7B).

GrowTH PARAMETERS OF ELONGATING TEPAL TISSUES. In 'Oxford' cut flowers, water potential of the water source was considered equivalent to that of vase solution, and water potentials of the sucrose-containing solution and the trehalose-containing solution were $-0.14 \pm 0.01(n=23) \mathrm{MPa}$ and $-0.14 \pm 0.04(n=16) \mathrm{MPa}$, respectively. The water potential of the vase solution decreased from -0.12 to $-0.14 \mathrm{MPa}$ after inserting flowers in the solution for one day, indicating that osmotically active solutes leaked out slightly from plants. For the intact pot-grown 'Oxford,' water potential of the water source was considered equivalent to that of the mature zone of roots, and was $-0.15 \pm 0.04(n=26) \mathrm{MPa}$. In 'Pink Diamond' cut flowers, $5{ }^{\circ} \mathrm{C}$-treated flowers were used for growth parameter determination experiments, and water potential of the water source was $\approx 0 \mathrm{MPa}$.

When the relative growth rates were plotted against the growthinduced water potential, linear relations through the origin were obtained in all treatments (Fig. $8 \mathrm{~A}$ and C). In 'Oxford' tepals, the hydraulic conductance (slope of the line) of sucrose-fed flowers was the highest, followed by the intact plants, trehalose-fed flowers and $5{ }^{\circ} \mathrm{C}$-kept flowers (Fig. 8A). When 'Pink Diamond' cut flowers were transferred from 5 to $20^{\circ} \mathrm{C}$, the hydraulic conductance increased from $0.45 \times 10^{-5} \mathrm{~s}^{-1} \cdot \mathrm{MPa}^{-1}$ to $2.13 \times 10^{-5}$ $\mathrm{s}^{-1} \cdot \mathrm{MPa}^{-1}$ (Fig. 8C), indicating that tissue became 4.7 times more conductive hydraulically during growth recovery in tepals.

Turgor of tepals in the zone of elongation was not linearly related to the relative growth rate in all treatments (Fig. 8 B and D). Because turgor values seemed to be kept almost equivalent against wide ranges of the relative growth rate, it was considered that growth-effective turgor was not a limiting factor for growth, and $m$ was considered infinitely large (Fig. 8 B and D).

TURGOR RELAXATION MEASUREMENTS IN INTACT AND EXCISED TEPALS. In order to ensure the completion of wall relaxation after excision, the time duration for the psychrometric water potential measurement was extended up to $10 \mathrm{~h}$, and thus, samples in the psychrometer chamber were kept between 3 and $10 \mathrm{~h}$ (Table 1). Cell turgor in the zone of elongation in intact tepals $\left(\Psi_{\mathrm{p}}\right.$ intact) was $0.54 \pm 0.06 \mathrm{MPa}$, and after excision cell turgor ( $\Psi_{\mathrm{p}}$ excision $)$ became $0.50 \pm$ $0.05 \mathrm{MPa}$ (Table 1). Thus, the reduction in potential due to wall relaxation after excision was thought to be $0.04 \mathrm{MPa}$.

Turgor measured with the psychrometer was $0.49 \pm 0.05 \mathrm{MPa}$, and practically equal to $\Psi_{\mathrm{p}}$ excision (Table 1). Because measurements were conducted in the same individual tissues, cell sap $\Psi_{\mathrm{s}}$ was also almost equal to $\Psi_{\mathrm{s}}$ measured with the psychrometer (Table 1). Therefore, the $\Psi_{w}$ measured with the psychrometer was thought to be a potential measured after wall relaxation. However, the effect of wall relaxation on the $\Psi_{\mathrm{w}}$ measurements was considered small because most actively growing tepal tissues exhibited approximately $0.04 \mathrm{MPa}$ of relaxation after excision, and the relaxation should be less when growth of tepals was reduced by stresses. The effect of excision on the $\Psi_{\mathrm{w}}$ determinations related to the growth parameters in Lockhart's combined equation will be further discussed.

\section{Discussion}

EFFECTS OF THE WALL RELAXATION DUE TO EXCISION ON GROWTH PARAMETERS. It is known that excision sometimes induces wall relaxation in actively growing tissue in plants (Boyer et al., 1985; Cosgrove et al., 1984). We also recognized that wall relaxation occurred after excision in the zone of elongation in tulip tepals, and such a relaxation made the value of water potential look slightly lower when the water status in actively growing tissue was measured with the psychrometer after excision. When nongrowing tissue was used for water potential determinations with the psychrometer, because no significant wall relaxation was caused by excision, water potential could be measured accurately as shown in Fig. 2. Thus, we attempted to correct values of the growth parameters after considering the effects of wall relaxation due to excision on the water potential determinations with the psychrometer.

When the turgor relaxation was measured with the pressure probe and the psychrometer in 'Pink Diamond' tepals in Table 1 , the growth rate was $($ mean $\pm \mathrm{SD}) 0.048 \pm 0.011 \mu \mathrm{m} \cdot \mathrm{s}^{-1}(\mathrm{n}=9)$ and the relaxation potential was $0.04 \mathrm{MPa}$ (Table 1). Although we did not measure the relaxation potential directly in the zone 
Table 1. Effects of excision on cell turgor $\left(\Psi_{\mathrm{p}}\right)$ of elongating tulip 'Pink Diamond' tepals measured with the pressure probe. Turgor ( $\Psi_{\mathrm{p}}$ intact $)$ of the epidermal cells in the zone of elongation (1.0 to $2.0 \mathrm{~cm}$ from the uppermost node) of intact outer tepals was measured with the pressure probe. The tissue adjacent to tissue measured with the pressure probe was removed, and then the excised tissue water potential $\left(\Psi_{\mathrm{w}}\right)$ was measured isopiestically with the psychrometer. After $\Psi_{\mathrm{w}}$ measurement, turgor $\left(\Psi_{\mathrm{p}}\right.$ excision $)$ of the epidermal cells in the excised tissue was measured with the pressure probe. Tissue $\Psi_{\mathrm{p}}$ in the psychrometric measurements were calculated from differences between $\Psi_{\mathrm{w}}$ and $\Psi_{\mathrm{s}}$, which were measured with the psychrometer.

\begin{tabular}{|c|c|c|c|c|c|c|c|}
\hline \multirow[b]{2}{*}{ Sample No. } & \multicolumn{2}{|c|}{ Pressure P robe } & \multirow[b]{2}{*}{ Cell Sap $\Psi_{\mathrm{s}}^{\mathrm{z}}$} & \multirow[b]{2}{*}{$\Delta t_{\mathrm{Psy}}{ }^{\mathrm{y}}$} & \multicolumn{3}{|c|}{ Isopi estic Psychromet er } \\
\hline & Cell $\Psi_{\mathrm{p}}^{\text {intact }}$ & $\operatorname{Cedl} \Psi_{\mathrm{p}}^{\text {excision }}$ & & & $\Psi_{\mathrm{w}}$ & $\Psi_{\mathrm{s}}$ & $\Psi_{\mathrm{p}}$ \\
\hline & $\mathrm{MPa}$ & $\mathrm{MPa}$ & $\mathrm{MPa}$ & hrs & $\mathrm{MPa}$ & $\mathrm{MPa}$ & $\mathrm{MPa}$ \\
\hline 1 & $0.60 \pm 0.06(5)^{x}$ & $0.53 \pm 0.06(5)^{x}$ & -0.71 & 3.2 & -0.33 & -0.74 & 0.41 \\
\hline 2 & $0.59 \pm 0.04(3)$ & $0.50 \pm 0.02(4)$ & -0.99 & 3.2 & -0.39 & -0.95 & 0.54 \\
\hline 3 & $0.53 \pm 0.02(3)$ & $0.52 \pm 0.03(4)$ & -0.90 & 3.2 & -0.36 & -0.90 & 0.56 \\
\hline 4 & $0.53 \pm 0.06(4)$ & $0.49 \pm 0.06(5)$ & -0.77 & 4.1 & -0.34 & -0.80 & 0.46 \\
\hline 5 & $0.53 \pm 0.02(3)$ & $0.50 \pm 0.00(3)$ & -0.90 & 5.4 & -0.46 & -0.94 & 0.48 \\
\hline 6 & $0.53 \pm 0.08(4)$ & $0.48 \pm 0.04(4)$ & -0.77 & 5.8 & -0.24 & -0.76 & 0.52 \\
\hline 7 & $0.46 \pm 0.06(3)$ & $0.42 \pm 0.01(3)$ & -0.86 & 10.0 & -0.38 & -0.84 & 0.46 \\
\hline Mean \pm SD & $\begin{array}{c}0.54 \pm 0.06 \\
(\mathrm{n}=25)\end{array}$ & $\begin{array}{c}0.50 \pm 0.05 \\
(\mathrm{n}=28)\end{array}$ & $\begin{array}{c}-0.84 \pm 0.10 \\
(\mathrm{n}=7)\end{array}$ & & $\begin{array}{c}-0.36 \pm 0.07 \\
(n=7)\end{array}$ & $\begin{array}{c}-0.85 \pm 0.08 \\
(\mathrm{n}=7)\end{array}$ & $\begin{array}{c}0.49 \pm 0.05 \\
(\mathrm{n}=7)\end{array}$ \\
\hline
\end{tabular}

${ }^{2}$ Cell Sap $\Psi_{\mathrm{s}}$ indicates the $\Psi_{\mathrm{s}}$ of cell sap of tissue where cell turgor was measured with the pressure probe prior to excision for the $\Psi_{\mathrm{w}}$ measurements.

${ }^{y} \Delta \mathrm{t}_{\mathrm{Psy}}$ indicates time required $\Psi_{\mathrm{w}}$ measurements with the isopiestic psychrometer.

${ }^{x}$ Data are the mean $\pm \mathrm{SD}$, and number in parenthesis indicates the number of epidermal cells in the abaxial side measured with the pressure probe.

of elongation in 'Oxford' tepals, we assumed that the relaxation potential could be proportional to the speed of growth because the relaxation potential should be almost proportional to the size of the effective turgor according to Boyer et al. (1985). The growth rate of 'Oxford' tepals became 1.96 times larger than that of 'Pink Diamond' tepals as the growth rate in 'Oxford' tepals of intact pot-grown plants at $20^{\circ} \mathrm{C}$ and 'Pink Diamond' tepals of $50 \mu \mathrm{M}$ CAP treated cut flowers at $20{ }^{\circ} \mathrm{C}$ at Score 0.1 was (mean \pm SD) $0.092 \pm 0.034 \mu \mathrm{m} \cdot \mathrm{s}^{-1}(\mathrm{n}=8)$ and $0.048 \pm 0.011 \mu \mathrm{m} \cdot \mathrm{s}^{-1}(\mathrm{n}=9)$, respectively. Thus, the magnitude of wall relaxation in 'Oxford' tepals was estimated to be $0.08 \mathrm{MPa}$, which was 1.96 times larger than that of 'Pink Diamond' tepals when relative growth rate $(\mathrm{RGR})>0.2 \times 10^{-5} / \mathrm{s}$. Because the nongrowing tissue did not exhibit the relaxation, we assumed that the relaxation was negligibly small when the RGR was lower than $0.2 \times 10^{-5} / \mathrm{s}$, and the psychrometric measurements would exhibit real values in intact plants. On such assumptions, Fig. 9 is drawn for corrected growth parameters for the control. In 'Oxford' tepals, $L$ shifted from $1.02 \times 10^{-5} \mathrm{~s}^{-1} \cdot \mathrm{MPa}^{-1}$ to $1.32 \times 10^{-5} \mathrm{~s}^{-1} \cdot \mathrm{MPa}^{-1}$ (Fig. 9A), $m$ from $+\infty$ to $43.10 \times 10^{-5} \mathrm{~s}^{-1} \cdot \mathrm{MPa}^{-1}$ (Fig. 9B), and $Y$ from 0.63 to $0.68 \mathrm{MPa}$ (Fig. 9B). In 'Pink Diamond' tepals, $L$ shifted from 2.13 $\times 10^{-5} \mathrm{~s}^{-1} \cdot \mathrm{MPa}^{-1}$ to $2.51 \times 10^{-5} \mathrm{~s}^{-1} \cdot \mathrm{MPa}^{-1}$ (Fig. 9C), and $m$ from $+\infty$ to $9.29 \times 110^{-5} \mathrm{~s}^{-1} \cdot \mathrm{MPa}^{-1}$ (Fig. 9D). The $Y$ was $0.47 \mathrm{MPa}$ and did not shift after the correction (Fig. 9D). It is noteworthy that $m$ became finite numbers in both 'Oxford' and 'Pink Diamond' tepals after correction due to wall relaxation, although $m$ were still relatively large, compared with $L$.

Predominant growth parameters for regulating Cell ELONGation. We postulate that Eq. [3] is satisfied when cell elongation is taking place at the steady state. Also, $Y$ was assumed to be constant while the water status was measured with the psychrometer. Usually, measurements of water potential with the psychrometer were completed in 3-4 $\mathrm{h}$ as shown in Table
1. When the relaxation of $0.08 \mathrm{MPa}$ was assumed in 'Oxford' tepals, the shift of $Y$ was $0.05 \mathrm{MPa}$, i.e., from 0.63 to $0.68 \mathrm{MPa}$ (Fig. 9B). What will happen if more relaxation in water potential after excision takes place? If the relaxation of $0.10 \mathrm{MPa}$ is assumed in 'Oxford' tepals, values of $L, m$ and $Y$ will be $1.41 \times$ $10^{-5} \mathrm{~s}^{-1} \cdot \mathrm{MPa}^{-1}, 8.31 \times 10^{-5} \mathrm{~s}^{-1} \cdot \mathrm{MPa}^{-1}$, and $0.67 \mathrm{MPa}$, respectively. Thus, the line for $L$ will have a steeper slope than one shown in Fig. 9A, and the line for $m$ will have a less steep slope than the one shown in Fig. 9B (Lines are not shown). However, further wall relaxation from 0.08 to $0.10 \mathrm{MPa}$ due to excision will not shift $Y$ practically because $Y$ has shifted from 0.68 to $0.67 \mathrm{MPa}$, when more relaxation is assumed in 'Oxford' tepals. Therefore, it is most likely that $Y$ was not altered significantly during the water potential measurements with the psychrometer within 3-4 $\mathrm{h}$ after excision was made in the zone of elongation.

Even if the effect of wall relaxation on the water potential determination with the psychrometer in the excised tissue in the zone of elongation was taken into account for the interpretation of results shown in Fig. 8, values of $m$ were much larger than those of $L$. If $m$ is much larger than $L$, the coefficient of Eq. [3] can be approximated as follows:

$$
\frac{m L}{\mathrm{~m}+L} \cong \frac{m L}{m}=L
$$

Consequently, Eq. [3] can be modified as follows:

$$
G=L\left(\Psi_{\mathrm{o}}-\Psi_{\mathrm{s}}-Y\right)
$$

Therefore, it is safe to conclude that growth of tulip tepals was predominantly controlled by properties related to the hydraulic conductance. It is important to keep in mind that this conclusion does not necessarily deny the importance of the wall extensibility. Rather, it means that the wall extensibility was not a limiting factor for growth of tulip tepals in the present study. 


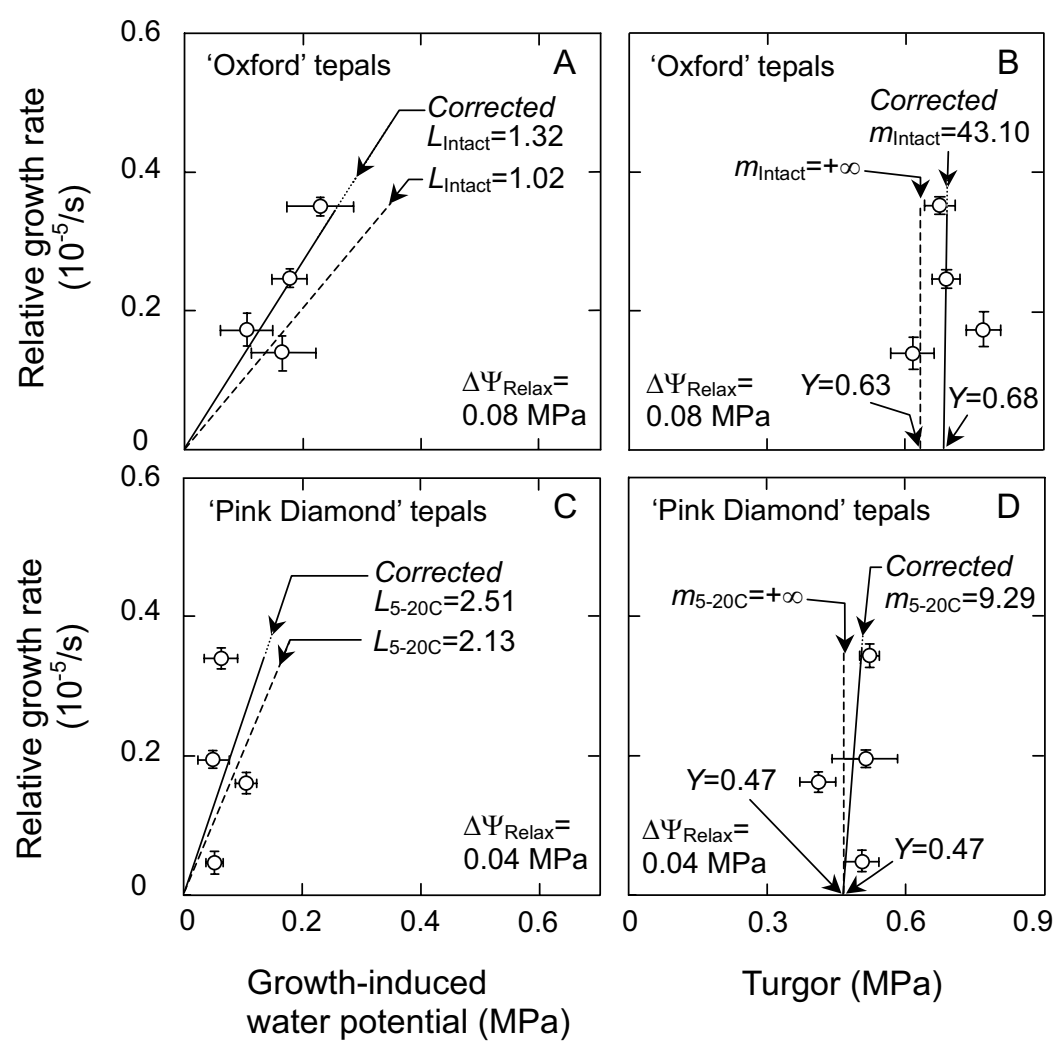

Fig. 9. Relative growth rates (RGRs) plotted against sizes of the corrected growth-induced water potential $(\mathbf{A}, \mathbf{C})$ and against corrected turgor $(\mathbf{B}, \mathbf{D})$ in the zone of elongation of intact flowers in 'Oxford' tepals $(\mathbf{A}, \mathbf{B})$ and treatment transferring 5 to $20^{\circ} \mathrm{C}$ in 'Pink Diamond' tepals $(\mathbf{C}, \mathbf{D})$, when it was assumed that the magnitudes of wall relaxation by excision in the zone of elongation (i.e., RGR > 0.2/s) in 'Oxford' and 'Pink Diamond' tepals were 0.08 MPa and 0.04 MPa, respectively (see "Discussion"). Vertical and horizontal bars indicate SE $(n=3-11)$. Dashed lines in A, B and $\mathrm{C}, \mathrm{D}$ indicate the regression lines of intact flowers in 'Oxford' tepals and treatment transferring 5 to $20^{\circ} \mathrm{C}$ in 'Pink Diamond' tepals shown in Fig. 8, respectively. In A-D, the corrected $L$ and the corrected $m$ were obtained from the slope of the line. The regression lines are as follows; (A) $y=1.32 x$ for intact flowers with $r^{2}=0.64$ (Corrected $L_{\text {Int }}=1.32$ ); (B) $y=43.10 x-29.44$, $r^{2}=0.01$ for intact flowers (Corrected $\left.m_{\text {Intact }}=43.10\right) ;(\mathbf{C}) y=2.51 x, r^{2}=0.01$ for treatment transferring 5 to $20{ }^{\circ} \mathrm{C}\left(\right.$ Corrected $\left.L_{5-20 \mathrm{C}}=2.51\right)$; (D) $y=9.29 x-4.35, r^{2}=0.07$ for treatment transferring 5 to $20^{\circ} \mathrm{C}\left(\right.$ Corrected $\left.m_{5-20 \mathrm{C}}=9.29\right)$.

When cell expansion is taking place, the cell wall must be pushed outward, and thus, the presence of turgor in the cell is essential for cell expansion to supply a force to push the wall toward the outside. Although turgor in the cell is required for growth, it was thought that the tissue-averaged growth-effective turgor was significantly or negligibly small in comparison with the sizes of the growth-induced water potential in the present study. Similar findings were made in tissue-cultured plants when cell elongation rates were reduced with the addition of 2,4-dichlorophenoxyacetic acid and benzylaminopurine (Ikeda et al., 1999) and trehalose (Ikeda et al., 2000). Although turgor was not a growth-limiting factor in the present study, turgor was related with maintenance of cell volume under trehalose treatment in cut flowers. Turgor was found to be not related with growth in some other instances (Meyer and Boyer, 1972; Nonami and Boyer, 1989; Zhu and Boyer, 1992). Contribution of turgor to growth was questioned in a study of cell expansion of Chara corallina Klien ex Willd. by Zhu and Boyer (1992). The cell elongation rate was highly dependent on energy metabolism as shown by inhibitors that rapidly abolished growth without changing the size of turgor (Zhu and Boyer, 1992). In many cases, turgor may not be a growth-limiting factor as demonstrated in the present study. Instead, Zhu and Boyer (1992) suggested that, above the turgor threshold, the rapid response to energy inhibitors indicated a control by metabolic reactions causing synthesis and/or extension of cell wall polymers.

The apoplast osmotic potential in tepals was high (Fig. 2C) and similar to water potentials of the zone of maturation in tepal tissues (Fig. 5A), and thus, solute concentrations in the apoplast must have been low. Because water must flow through the zone of elongation in tepals first, water potential of the xylem solution in the zone of elongation should not be lower than that of the mature zone in the same tepal tissue, and thus, low water potential in the zone of elongation in tepals (Fig. 5) was considered to be the water potential gradient associated with growth. This gradient was called the growth-induced water potential (Boyer, 1985; Moltz and Boyer, 1978; Nonami and Boyer, 1987, 1993). Sizes of the growth-induced water potential was proportional to those of the relative growth rate in the zone of elongation of tepal tissues dealt with in the present study. The slope, $L$, must represent intrinsic characteristics associated with growing conditions and treatments.

EFFeCt OF tREhalose ON THE VASE LIFE LONGEVITY. In the present study, tulip tepals were treated with $50 \mathrm{~mm}$ (i.e., 1.7\%) trehalose. Iwaya-Inoue and Takata (2001) investigated which concentration of trehalose in cut tulip flowers was the best for enhancing longevity of the vase life, and found that $50 \mathrm{~mm}$ trehalose was the optimum. It has been reported that wall synthesis was inhibited upon $2 \%$ trehalose feeding in dodder cells (Veluthambi et al., 1982). However, Ikeda et al. (2000) has reported that soybean embryos cultured on $1.5 \%$ and $3.0 \%$ trehalose-containing media grew better than those cultured on media without sugars, and thus, it was not evident that inhibition of wall synthesis took place. In the present study, the wall extensibilities of tulip tepals treated on sucrose- and trehalose-containing vase solution were similarly considered to be relatively large (Fig. $8 \mathrm{~B}$ and D). Thus, it is most likely that the wall extensibility was not a regulating factor for reduction in cell expansion rate in trehalose-fed tulip tepals in the present study.

It is known that CAP is an inhibitor of photosynthesis-related metabolisms in chloroplasts. For instance, in cells of Chlamydomonas reinhardtii Dangeard, treatment of $100 \mu \mathrm{g} \cdot \mathrm{mL}^{-1}(310 \mu \mathrm{M})$ and $36 \mathrm{~mm}$ CAP induced the significant decrease in chlorophyll fluorescence ratio $\left(\mathrm{F}_{\mathrm{v}} / \mathrm{F}_{\mathrm{m}}\right)$ (Saradhi et al., 2000) and PSI/PSII ratio (Murakami et al.,1997), respectively. Similarly, $F_{v} / F_{m}$ was markedly reduced by treating with $300 \mu \mathrm{g} \cdot \mathrm{mL}^{-1}(1 \mathrm{mM})$ CAP in leaves of Hordeum vulgare L. (Greer et al., 1991) and thallus of Ulva rotundata Blid. (Franklin, 1994). In the dark, the rate of photosynthesis in leaves of Oryza sativa L. as inhibited by treating with 3 mm CAP (Okada et al., 1991). However, much lower concentration of CAP is customarily used for cut flowers. It was reported that the vase life of flower splays of Dendrobium Momozono 'Princess' and four other Dendrobium Swartz species was prolonged by treating with $10 \mathrm{mg} \cdot \mathrm{L}^{-1}(\approx 31 \mu \mathrm{M})$ CAP rather than with the sterilized water (Dai and Paull, 1991). In the present study, we used $50 \mu \mathrm{M}$ CAP in plants with leaves in the dark or in plants without leaves under very low $P P F$. Thus, the effect of 
CAP solution on photosynthesis-related metabolisms of the cut flower should be negligibly small in the present study.

Sucrose plays a role as an important energy source for respiration and also as substrates for structural materials in cut flowers (Halevy and Mayak, 1979). In 'Pink Diamond,' the tepal growth in the sucrose-containing solution was better than that in the control although the sucrose-containing solution $(-0.12 \mathrm{MPa}$ of water potential) had slightly lower water potential than the control solution $(\approx 0 \mathrm{MPa}$ of water potential) (Fig. 7B), indicating that sucrose was contributing to cell elongation as an extra carbon source and/or energy source. It is well known that longevity of the vase life is increased by feeding sucrose to cut flowers, such as rose (Rosa hybrida L.) (Ichimura et al., 1999; Kuiper et al., 1995), carnation (Dianthus caryophyllus L.) (Koyama and Uda, 1994; Paulin and Jamain, 1982), sweet pea (Lathyrus odoratus L.) (Ichimura and Hiraya, 1999).

On the other hand, trehalose enhanced the vase life in tepals of cut tulip flowers (Fig. 3A, Iwaya-Inoue and Nonami, 2003; IwayaInoue and Takata, 2001) by reducing the growth rates (Figs. 6 and 7). When the vase solution was changed from the CAP solution to the sucrose-containing solution, tepal growth increased and its growth rate reached a higher rate, and when it was changed from the sucrose-containing solution to the trehalose-containing solution, the growth rate decreased to a lower steady rate (Fig. 6). Re-changing the vase solution from the trehalose-containing to the sucrose-containing solution made the growth rate recover to the previous higher steady state (Fig. 6A). Thus, changes in $L$ associated with growth of tepals seemed to be reversible within a relatively short time. Therefore, it is very unlikely that cell division or differentiation of vascular systems took place within such a short period, and it is most likely that cell elongation rate was modified due to the change in $L$.

It was suggested that changes in $L$ characterize cell membrane hydraulic properties and are metabolically regulated (Nonami and Boyer, 1990a, 1990b). When trehalose was fed to elongating tepals, $L$ was decreased more than in the control (Fig. 8A), and turgor was maintained at a high level for a longer time than in the control (Fig. 3B). Iwaya-Inoue and Nonami (2003) showed with the tetranitroblue tetrazolium staining technique that trehalose preserved tissue viability of the tulip tepals for longer periods. Additionally, trehalose-fed tepals had stronger pigmentation than the control since chroma (vividness of color) in trehalosefed flowers was significantly higher (Fig. 3C). It is obvious that trehalose modified metabolisms related to cell turgor maintenance in tepal tissues and caused changes in $L$ associated with cell elongation. Our findings suggest that reduction in cell expansion rates in trehalose-fed tulip tepals was related to reduction in the hydraulic conductance.

\section{Literature Cited}

Boyer, J.S. 1967. Leaf water potentials measured with a pressure chamber. Plant Physiol. 42:133-137.

Boyer, J.S. 1974. Water transport in plants: Mechanism of apparent changes in resistance during absorption. Planta 117:187-207.

Boyer, J.S. 1985. Water transport. Annu. Rev. Plant Physiol. 36:473516.

Boyer, J.S. 1995. Measuring the water status of plants and soils. Academic, San Diego.

Boyer, J.S., A.J. Cavalieri, and E.-D. Schulze. 1985. Control of the rate of cell enlargement: Excision, wall relaxation, and growth-induced water potentials. Planta 163:527-543.

Cosgrove, D.J., E. Van Volkenburgh, and R.E. Cleland. 1984. Stress relaxation of cell walls and the yield threshold for growth: Demonstration and measurement by micro-pressure probe and psychrometer techniques. Planta 162:46-54.

Crowe, J.H., L.M. Crowe, and D. Chapman. 1984. Preservation of membranes in anhydrobiotic organisms: The role of trehalose. Science 223:701-703.

Dai, J. and R.E. Paull. 1991. Effect of water status on Dendrobium flower spray postharvest life. J. Amer. Soc. Hort. Sci. 116:491-496.

Ehlig, C.F. 1962. Measurement of energy status of water in plants with a thermocouple psychrometer. Plant Physiol. 37:288-290.

Esau, K. 1977. Anatomy of seed plants. 2nd ed. Wiley, New York.

Franklin, L.A. 1994. The effects of temperature acclimation on the photoinhibitory responses of Ulva rotundata Blid. Planta 192: 324-331.

Green, P.B., R.O. Erickson, and J. Buggy. 1971. Metabolic and physical control of cell elongation rate: in vivo studies in Nitella. Plant Physiol. 47:423-430.

Greer D.H., C. Ottander, and G. Öquist. 1991. Photoinhibition and recovery of photosynthesis in intact barley leaves at 5 and $20{ }^{\circ} \mathrm{C}$. Physiol. Plant. 81:203-210.

Halevy, A.H. and S. Mayak, 1979. Senescence and postharvest physiology of cut flowers, part 1. Hort. Rev. 1. 204-236.

Hottiger, T., C. De Virgilio, M.N. Hall, T. Boller, and A. Wiemken. 1994. The role of trehalose synthesis for the acquisition of thermotolerance in yeast II. Physiological concentrations of trehalose increase the thermal stability of proteins in vitro. Eur. J. Biochem. 219:187-193.

Hsiao, T.C., E. Acevedo, E. Fereres, and D.W. Henderson. 1976. Water stress, growth, and osmotic adjustment. Phil. Trans. Roy. Soc. London Ser. B 273:479-500.

Hunter, R.S. 1975. The measurement of appearance. Wiley, New York.

Hüsken, D., E. Steudle, and U. Zimmermann. 1978. Pressure probe technique for measuring water relations of cells in higher plants. Plant Physiol. 61:158-163.

Ichimura, K. and T. Hiraya. 1999. Effect of silver thiosulfate complex (STS) in combination with sucrose on the vase life of cut sweet pea flowers. J. Jpn. Soc. Hort. Sci. 68:23-27.

Ichimura, K., K. Kojima, and R. Goto. 1999. Effects of temperature, 8-hydroxyquinoline sulphate and sucrose on the vase life of cut rose flowers. Postharvest Biol. Technol. 15:33-40.

Ikeda, T., M. Iwaya-Inoue, T. Fukuyama, and H. Nonami. 2000. Trehalose changes hydraulic conductance of tissue-cultured soybean embryos. Plant Biotechnol. 17:119-125.

Ikeda, T., H. Nonami, T. Fukuyama, and Y. Hashimoto. 1999. Hydraulic contribution in cell elongation of tissue-cultured plants: Growth retardation induced by osmotic and temperature stresses and addition of 2,4-dichlorophenoxyacetic acid and benzylaminopurine. Plant Cell Environ. 22:899-912.

Iwaya-Inoue, M. and H. Nonami. 2003. Effects of trehalose on flower senescence from the view point of physical states of water. Environ. Control in Biol. 41:3-15.

Iwaya-Inoue, M. and M. Takata. 2001. Trehalose plus chloramphenicol prolong the vase life of tulip flowers. HortScience 36:946-950.

Jones, R.B. and M. Hill. 1993 The effect of germicides on the longevity of cut flowers. J. Amer. Soc. Hort. Sci. 118: 350-354.

Jones, R.B., M. Serek, C.-L. Kuo, and M.S. Reid. 1994. The effect of protein synthesis inhibition on petal senescence in cut bulb flowers. J. Amer. Soc. Hort. Sci. 119:1243-1247.

Koyama, Y. and A. Uda. 1994. Effect of temperature, light intensity and sucrose concentration on bud forcing and carnation flower quality (in Japanese with English summary). J. Jpn. Soc. Hort. Sci. 63:203-209.

Kuiper, D., S. Ribot, H.S. van Reenen, and N. Marissen. 1995. The effect of sucrose on the flower bud opening of 'Madelon' cut roses. Scientia Hort. 60:325-336.

Lee, C.W.B., S.K. Das Gupta, J. Mattai, G.G. Shipley, O.H. Abdel-Mageed, A. Makriyannis, and R.G. Griffin. 1989. Characterization of the $\mathrm{L}_{\lambda}$ phase in trehalose-stabilized dry membranes by solid-state NMR and X-ray diffraction. Biochemistry 28:5000-5009. 
Lockhart, J.A. 1965a. An analysis of irreversible plant cell elongation. J. Theor. Biol. 8:264-275.

Lockhart, J.A. 1965b. Cell extension, p. 826-849. In: J. Bonner and J.E. Varner (eds.). Plant biochemistry. Academic, New York.

McGuire, R.G. 1992. Reporting of objective color measurements. HortScience 27:1254-1255.

Meyer, R.F. and J.S. Boyer. 1972. Sensitivity of cell division and cell elongation to low water potentials in soybean hypocotyls. Planta 108:77-87.

Moltz, F.J. and J.S. Boyer. 1978. Growth-induced water potentials in plant cells and tissues. Plant Physiol. 62:423-429.

Murakami, A., Y. Fujita, J.A. Nemson, and A. Melis. 1997. Chromatic regulation in Chlamydomonas reinhardtii: Time course of photosystem stoichiometry adjustment following a shift in growth light quality. Plant Cell Physiol. 38:188-193.

Nonami, H. and J.S. Boyer. 1987. Origin of growth-induced water potential: Solute concentration is low in apoplast of enlarging tissues. Plant Physiol. 83:596-601.

Nonami H. and J.S. Boyer. 1989. Turgor and growth at low water potentials. Plant Physiol. 89:798-804.

Nonami, H. and J.S. Boyer. 1990a. Primary events regulating stem growth at low water potentials. Plant Physiol. 93:1601-1609.

Nonami, H. and J.S. Boyer. 1990b. Wall extensibility and cell hydraulic conductivity decrease in enlarging stem tissues at low water potentials. Plant Physiol. 93:1610-1619.

Nonami,H. and J.S. Boyer. 1993. Direct demonstration of growth-induced water potential gradient. Plant Physiol. 102:13-19.

Nonami, H., Y. Wu, and J.S. Boyer. 1997. Decreased growth-induced water potential: A primary cause of growth inhibition at low water potentials. Plant Physiol. 114:501-509.
Okada, K., K. Satoh, and S. Katoh. 1991. Chloramphenicol is an inhibitor of photosynthesis. FEBS Lett. 295:155-158.

Paulin, A. and C. Jamain. 1982. Development of flowers and changes in various sugars during opening of cut carnations. J. Amer. Soc. Hort. Sci. 107:258-261.

Ray, P.M. and A.W. Ruesink. 1963. Osmotic behavior of oat coleoptile tissue in relation to growth. J. Gen. Physiol. 47:83-101.

Ray, P.M., P.B. Green and R. Cleland. 1972. Role of turgor in plant cell growth. Nature 239:163-164.

Saradhi, P.P., I. Suzuki, A. Katoh, A. Sakamoto, P. Sharmila, and D.J. Shi. 2000. Protection against the photo-induced inactivation of the photosystem II complex by abscisic acid. Plant Cell Environ. 23:711-718.

Scholander, P.F., H.T. Hammel, E.D. Bradstreet, and E.A. Hemmingsen. 1965. Sap pressure in vascular plants: Negative hydrostatic pressure can be measured in plants. Science 148:339-346.

Silk, W.K. and K.K. Wagner. 1980. Growth-sustaining water potential distributions in the primary corn root: Anoncompartmented continuum model. Plant Physiol. 66:859-863.

van Doorn, W.G. 1997. Water relations of cut flowers. Hort. Rev. 18:1-85.

Veluthambi, K., S. Mahadevan, and R. Maheshwari. 1981. Trehalose toxicity in Cuscuta reflexa: Correlation with low trehalase activity. Plant Physiol. 68:1369-1374.

Veluthambi, K., S. Mahadevan, and R. Maheshwari. 1982. Trehalose toxicity in Cuscuta reflexa: Cell wall synthesis is inhibited upon trehalose feeding. Plant Physiol. 70:686-688.

Zhu, G-L. and J.S. Boyer. 1992. Enlargement in Chara studied with a turgor clamp: Growth rate is not determined by turgor. Plant Physiol. 100:2071-2080. 